Atmos. Chem. Phys., 13, 2703-2719, 2013

www.atmos-chem-phys.net/13/2703/2013/

doi:10.5194/acp-13-2703-2013

(C) Author(s) 2013. CC Attribution 3.0 License.

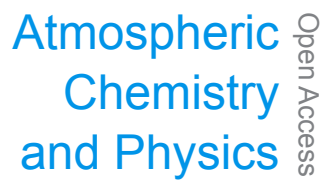

(C) (P)

\title{
Chemical characterization and stable carbon isotopic composition of particulate Polycyclic Aromatic Hydrocarbons issued from combustion of 10 Mediterranean woods
}

\author{
A. Guillon ${ }^{1,2}$, K. Le Ménach ${ }^{1,2}$, P.-M. Flaud ${ }^{1,2}$, N. Marchand ${ }^{3}$, H. Budzinski ${ }^{1,2}$, and E. Villenave ${ }^{1,2}$ \\ ${ }^{1}$ CNRS, EPOC, UMR5805, 33400 Talence, France \\ ${ }^{2}$ Univ. Bordeaux, EPOC, UMR5805, 33400 Talence, France \\ ${ }^{3}$ Universités d'Aix-Marseille-CNRS, 6264, Laboratoire Chimie Provence, Equipe Instrumentation et Réactivité \\ Atmosphérique, Marseille, 13331, France
}

Correspondence to: E. Villenave (eric.villenave@u-bordeaux1.fr)

Received: 29 May 2012 - Published in Atmos. Chem. Phys. Discuss.: 17 August 2012

Revised: 16 November 2012 - Accepted: 11 February 2013 - Published: 6 March 2013

\begin{abstract}
The objectives of this study were to characterize polycyclic aromatic hydrocarbons from particulate matter emitted during wood combustion and to determine, for the first time, the isotopic signature of PAHs from nine wood species and Moroccan coal from the Mediterranean Basin. In order to differentiate sources of particulate-PAHs, molecular and isotopic measurements of PAHs were performed on the set of wood samples for a large panel of compounds. Molecular profiles and diagnostic ratios were measured by gas chromatography/mass spectrometry (GC/MS) and molecular isotopic compositions $\left(\delta^{13} \mathrm{C}\right)$ of particulate-PAHs were determined by gas chromatography/combustion/isotope ratio mass spectrometry (GC/C/IRMS). Wood species present similar molecular profiles with benz(a)anthracene and chrysene as dominant PAHs, whereas levels of concentrations range from 1.8 to $11.4 \mathrm{mg} \mathrm{g}^{-1} \mathrm{OC}$ (sum of PAHs). Diagnostic ratios are consistent with reference ratios from literature but are not sufficient to differentiate the species of woods. Concerning isotopic methodology, PAH molecular isotopic compositions are specific for each species and contrary to molecular fingerprints, significant variations of $\delta^{13} \mathrm{C}$ are observed for the panel of PAHs. This work allows differentiating wood combustion (with $\delta^{13} \mathrm{C}_{\mathrm{PAH}}=-28.7$ to $-26.6 \%$ ) from others origins of particulate matter (like vehicular exhaust) using isotopic measurements but also confirms the necessity to investigate source characterisation at the emission in order to help and complete source assessment mod-
\end{abstract}

els. These first results on woodburnings will be useful for the isotopic approach to source tracking.

\section{Introduction}

Polycyclic Aromatic Hydrocarbons (PAHs) are ubiquitous compounds in the environment, detected in various compartments such as water (Latimer and Zheng, 2003; Amoako et al., 2011), sediments (Latimer and Zheng, 2003; Srogi, 2007; Van Drooge et al., 2011), soils (Jensen et al., 2007; García-Alonso et al., 2008; Desaules et al., 2008), organisms (Meador, 2003; Perugini et al., 2007; Srogi, 2007) or air (Ravindra et al., 2008; Van Drooge and Ballesta, 2009; Yan et al., 2009; Sheesley et al., 2011). Most of PAHs come from the incomplete combustion of organic materials and are potentially carcinogenic and mutagenic for human beings (Atkinson and Arey, 1994; Kang et al., 2011; IARC, 2011). In the atmosphere, they are distributed between gaseous phase and particles (Eiguren-Fernandez et al., 2004; Ré-Poppi and Santiago-Silva, 2005). The main origins of particulate-PAHs are anthropogenic such as emissions from domestic (residential heating) and industrial activities, agriculture and vehicular exhausts. Wood combustion represents a non-negligible origin of particulate-PAHs because of a variety of human activities involving biomass

Published by Copernicus Publications on behalf of the European Geosciences Union. 
burning such as building heating, cooking (Lee et al., 2005) or swidden, slash-and-burn farming, but also because of natural wood combustions (forest fires).

The identification and the apportionment of PAH sources are related to the description of source characteristics, for example molecular and isotopic features. Several methodologies of source tracking were developed on the measurements of particulate-PAH concentrations and on the use of molecular profiles and diagnostic ratios (Guo et al., 2003; Dallarosa et al., 2005; Ravindra et al., 2008). Some studies reported the concentrations of a large range of particulate-PAHs emitted for instance during the combustion of different wood species in the United States of America thus contributing to the characterization of molecular profiles at the emission (Fine et al., 2001, 2002, 2004). For example, their data are considered in several studies as wood combustion fingerprints for source apportionment using a Chemical Mass Balance model (Yang and Chen, 2004; Sheesley et al., 2008). Nevertheless, due to the large variety of wood species and the fairly high heterogeneous reactivity of PAH compounds in the atmosphere, involving variations of concentrations and diagnostic ratios, it is sometimes risky to apportion particulate-PAH sources by only applying such approaches.

More recently, methodologies based on the molecular stable-carbon isotopic compositions allow source studies by identifying characteristic isotopic fingerprints for different compounds in the atmosphere (Bendle et al., 2007; Li et al., 2010; Sang et al., 2012). If chemical reactions usually result in isotopic ${ }^{13} \mathrm{C}$ fractionation when occurring in the gas phase, there was up to now no available data concerning isotopic variations during atmospheric heterogeneous processes (which are the most efficient in the troposphere in the case of PAHs). The only study has been recently performed by our group (Guillon et al., 2013a), showing that no significant fractionation occurred during reactions of particulate-PAHs with $\mathrm{O}_{3}, \mathrm{OH}$ and $\mathrm{NO}_{\mathrm{x}}$ or under solar irradiance, of atmospheric interest. Such result is important because potential isotopic variations induced by heterogeneous chemical reactions are much lower than uncertainties on GC/C/IRMS measurements and also considering the larger range of variations of $\delta^{13} \mathrm{C}$ of particulate-PAHs from different sources. Considering wood combustion, two studies performed isotopic composition measurements of PAHs (Ballentine et al., 1996; O'Malley et al., 1997) and show that isotopic compositions of $\mathrm{C} 3$ and $\mathrm{C} 4$ plants could be differentiated by PAH molecular isotopic compositions. In order to contribute to the development of source tracking for particulate-PAHs, ten Mediterranean wood species were burned in a combustion chamber to identify molecular and isotopic fingerprints of emitted particulate-PAHs. Concentrations of a large panel of PAHs were measured by GC/MS and the determination of molecular stable-carbon isotopic compositions was performed by GC/C/IRMS. The aim of these measurements was to characterize combustion emissions of several wood species, potentially involved in the pollution of Mediterranean area dur- ing biomass burning and forest fire episodes and largely, to provide molecular isotopic signatures of wood burnings for source assessment in Europe.

\section{Experimental procedure}

\subsection{Description of wood species}

A variety of wood species from the Mediterranean Basin was selected for the study of particulate matter emitted during wood combustion. Collection of woods was performed in the natural park of "Calanques de Marseille" (France). Table 1 summarizes the main characteristics of the selected woods: nine plant species and eucalyptus Moroccan coal which is commonly used in North African countries for cooking preparation.

Note that some woods were studied several times in order to compare different conditions of combustion and the way of wood cutting prior to experiments. Organic and elemental carbon (OC and EC) measurements were not performed on the entire panel of wood species. After collection, all wood samples were dried up at $50^{\circ} \mathrm{C}$ during two days.

\subsection{Setup for wood combustion}

Wood combustion experiments were carried out at Lannemezan in the combustion facility (Pham-Van-Dinh et al., 1994; Garivait, 1995) of the Laboratory d'Aérologie (UMR 5560, Toulouse, France) made up of three chambers: the fireplace, the mixing chamber $\left(120 \mathrm{~m}^{3}\right)$ and the laboratory for measurement monitoring. The fireplace was equipped with a chimney allowing the circulation of smoke to the mixing chamber by a trap door. The internal surface of this chamber was rendering. Approximately $100 \mathrm{~g}$ of each wood were burned in the fireplace and once combustion was stabilized, smoke was injected in the mixing chamber by opening the trap door. After $5 \mathrm{~min}$, the door was closed and two fans were activated to homogenize the repartition of products of combustion (particles and gases) in all the volume of the mixing chamber prior to sampling. Samples were collected for $20 \mathrm{~min}$ (Table 1). At the end of each combustion experiment, the mixing chamber was vented in order to renew the full atmosphere between two experiments.

\subsection{Sample collection}

Wood combustion aerosol particles with aerodynamic diameters less than $2.5 \mu \mathrm{m}$ were collected on quartz filters $(150 \mathrm{~mm}$ diameter, Whatman, Q-MA) using a high-volume sampler (Mégatec Digitel DA-80, 30 $\mathrm{m}^{3} \mathrm{~h}^{-1}$ ). Collection was performed for around $20 \mathrm{~min}$ corresponding to a sampling volume of $(10 \pm 1.3) \mathrm{m}^{3}$ for the different species, except for eucalyptus Moroccan coal (sampling time of 77 min corresponding to a volume of $36.6 \mathrm{~m}^{3}$ ). Filter blanks (consisting in exposed filter without any air filtration, under the same 
Table 1. Description of wood species studied in this work.

\begin{tabular}{|c|c|c|c|c|c|c|c|}
\hline Common name & Botanical name & Wood family & $\begin{array}{l}\text { condition of } \\
\text { combustion }\end{array}$ & $\begin{array}{c}\text { Volume of } \\
\text { sampling }\left(\mathrm{m}^{3}\right)\end{array}$ & $\begin{array}{c}\text { Time of } \\
\text { sampling }(\min )\end{array}$ & $\begin{array}{c}\mathrm{OC} \\
\left(\mu \mathrm{g} \mathrm{m}^{-3}\right)\end{array}$ & $\begin{array}{c}\mathrm{EC} \\
\left(\mu \mathrm{g} \mathrm{m}^{-3}\right)\end{array}$ \\
\hline Cork oak-twigs 1 & Quercus Suber L & hardwood & smoldering & 8.90 & 21 & 3902 & 67 \\
\hline Cork oak-twigs 2 & Quercus Suber L & hardwood & flaming & 10.95 & 24 & n.a. & n.a. \\
\hline Cork oak & Quercus Suber L & hardwood & flaming & 9.43 & 20 & 304 & 16 \\
\hline Juniper tree & Juniperus & softwood & smoldering & 8.97 & 20 & n.a. & n.a. \\
\hline Rosemary & Rosmarinus Officinalis & hardwood & flaming & 11.01 & 24 & 1318 & 165 \\
\hline Alep pine 1 & Pinus Halepensis & softwood & flaming & 9.5 & 21 & 2923 & 223 \\
\hline Alep pine 2 & Pinus Halepensis & softwood & flaming & 9.05 & 20 & 3433 & 226 \\
\hline Green oak & Quercus Ilex & hardwood & flaming & 8.94 & 20 & 3395 & 188 \\
\hline "kermes" oak & Quercus Coccifera & hardwood & flaming & 10.33 & 24 & 515 & 57 \\
\hline Cypress 1 & Cupressus Sempervirens & softwood & smoldering & 8.13 & 21 & 12416 & 390 \\
\hline Cypress 2 & Cupressus Sempervirens & softwood & flaming & 11.05 & 25 & n.a. & n.a. \\
\hline Mediterranean False-Brome & Brachypodium Retusum & hardwood & flaming & 9.95 & 24 & 2298 & 22 \\
\hline Heather 1 & Erica Multiflore & hardwood & flaming & 9.53 & 21 & 1126 & 174 \\
\hline Heather 2 & Erica Multiflore & hardwood & smoldering & 13.19 & 29 & n.a. & n.a. \\
\hline Eucalyptus Moroccan coal & - & - & smoldering & 36.64 & 77 & 121 & $<1$ \\
\hline
\end{tabular}

conditions) were collected before each combustion experiment. Prior to sampling, all the quartz fibre filters were heated at $500^{\circ} \mathrm{C}$ during $4 \mathrm{~h}$. After sampling, filters were wrapped in aluminium foil, sealed in polyethylene bags and stored at $-20^{\circ} \mathrm{C}$. To perform different kinds of analysis on the same panel of wood combustions, filters were punched: $0.64 \mathrm{~cm}^{2}$ of each filter were used for the quantification of particulate-PAHs, $1 \mathrm{~cm}^{2}$ for the analysis of organic and elemental carbon (OC/EC) and remaining of filters were used to determine the isotopic compositions of PAHs by GC/C/IRMS.

EC and OC measurements were performed on $1 \mathrm{~cm}^{2}$ of each filter using a Thermo-Optical Transmission (TOT) method on a Sunset Lab analyser (Birch and Cary, 1996) implemented with the EUSAAR_2 method (Cavalli et al, 2010).

\subsection{Analytical procedure}

\subsubsection{Quantification of PAHs}

\section{Extraction}

Pressurised fluid extractions (PFE) were performed using accelerated solvent extractor ASE 350 (Dionex SA). This technique was validated and largely employed for the certification of NIST materials such as SRM 1649a or SRM 2975 (Schantz et al., 1997). In our study, extractions were performed in dichloromethane ("For residue and pesticides analysis" type, Acros Organics) under the following parameters: $T=100^{\circ} \mathrm{C}, P=100$ Bars, heating time of 6 min with 2 static cycles of $8 \mathrm{~min}$. Different sizes of ASE stainless steel cells were employed for the different extraction required in this study in order to optimize the volume of solvent against the volume occupied by the filter or the punch in the cell. For quantification measurements, standard reference materials (previously deposited on glass fibre filters), punches of $0.64 \mathrm{~cm}^{2}$ of sampled filters and punches of
$16.62 \mathrm{~cm}^{2}$ of blank filters were extracted in $10 \mathrm{~mL}$ cells. For isotopic measurements, remaining parts of each filter were extracted in $34 \mathrm{~mL}$ cells. Prior to the extraction, a cellulose filter (19.8 mm diameter, Dionex SA) was placed at the bottom of the cell and one third of the cell was filled up with 2.0mm-diameter glass beads (A556, Roth) previously cleaned and heated at $450{ }^{\circ} \mathrm{C}$ during $4 \mathrm{~h}$. Filters folded in four were placed in the cell and the volume was completed with glass beads in order to minimize the dead volume. For quantitative measurements by GC-MS, internal standards $(20 \mu \mathrm{L}$ per samples; $2 \mu \mathrm{g} \mathrm{g}^{-1}$ of deuterated PAH in isooctane) were added gravimetrically in the cell and then, the cell was completely filled with glass beads. After the extraction, filtration was performed in the PFE cell through the cellulose filter. Solution of internal standards was prepared by dissolving crystals of deuterated PAHs in isooctane.

Moreover, the cells filled with the cellulose filter and glass beads were pre-extracted using the same extraction conditions as for the samples.

\section{Purification}

After extraction and filtration, the extract was concentrated in approximately $500 \mu \mathrm{L}$ in the extraction solvent using a vacuum evaporation system (RapidVap, Labconco), under the following conditions: vortex motion $(70 \%)$, vacuum (900 mBars) and heat $\left(51^{\circ} \mathrm{C}\right)$. Different purification steps were then required to remove all undesirable organic compounds that could interfere in the PAH analysis. The extract was first purified on a micro-column containing activated copper (copper powder, 40 mesh, Sigma-Aldrich) which allowed sulphur elimination, and alumina (aluminium oxide, 150 Basic Type T, Merck, VWR) in order to remove macromolecules present in these complex matrices such as lipids or pigments, by eluting PAHs with $3 \times 5 \mathrm{~mL}$ of dichloromethane. The extract was then concentrated with 
Table 2. List of studied PAHs with the corresponding internal and "syringe" standards.

\begin{tabular}{|c|c|c|c|}
\hline Native PAHs & Abbreviations & Internal Standards & "Syringe" Standards \\
\hline Naphthalene & Naph & Naphthalene d8 & \multirow{13}{*}{ Pyrene-d10 } \\
\hline Acenaphtylene & Acy & & \\
\hline Acenaphtene & Ace & & \\
\hline Fluorene & & Phenanthrene d10 & \\
\hline Phenanthrene * & Phen & & \\
\hline Anthracene & Anth & Anthracene d10 & \\
\hline Dibenzothiophene & $\mathrm{DBT}$ & Dibenzothiophene $\mathrm{d} 8$ & \\
\hline $\begin{array}{l}\text { Fluoranthene * } \\
\text { Pyrene * }\end{array}$ & $\begin{array}{l}\text { Fluo } \\
\text { Pyr }\end{array}$ & Fluoranthene d10 & \\
\hline Benzo(ghi)fluoranthene & BghiF & \multirow{5}{*}{ Chrysene d12 } & \\
\hline Benzo(c)phenanthrene & $\mathrm{BcP}$ & & \\
\hline Benz(a)anthracene * & $\mathrm{BaA}$ & & \\
\hline Chrysene + Triphenylene $*$ & Chrys & & \\
\hline Cyclopenta(cd)pyrene & CcdP & & \\
\hline Benzo(b)fluoranthene * & $\mathrm{BbF}$ & \multirow{5}{*}{ Benzo(e)Pyrene d12 } & \multirow{17}{*}{ Benzo(b)fluoranthene d12 } \\
\hline Benzo(k)fluoranthene * & $\mathrm{BkF}$ & & \\
\hline Benzo(j)fluoranthene * & $\mathrm{BjF}$ & & \\
\hline Benzo(a)fluoranthene $*$ & $\mathrm{BaF}$ & & \\
\hline Benzo(e)pyrene * & $\mathrm{BeP}$ & & \\
\hline Benzo(a)pyrene * & $\mathrm{BaP}$ & Benzo(a)pyrene d12 & \\
\hline Perylene * & Per & Benzo(e)Pyrene d12 & \\
\hline Dibenzo(ac)anthracene & DBacA & \multirow{5}{*}{ Benzo(ghi)perylene d12 } & \\
\hline Indeno(1,2,3-cd)pyrene * & & & \\
\hline Dibenzo(ah)anthracene & DBahA & & \\
\hline Benzo(ghi)perylene * & BghiP & & \\
\hline Anthanthrene & Antha & & \\
\hline Coronene & Cor & \multirow{5}{*}{ Coronene $\mathrm{d} 12$} & \\
\hline Dibenzo(bk)fluoranthene & DbkF & & \\
\hline Dibenzo(al)perylene & DalP & & \\
\hline Dibenzo(ae)perylene & $\mathrm{DaeP}$ & & \\
\hline Dibenzo(ah)perylene & DahP & & \\
\hline
\end{tabular}

low heating $\left(T=40^{\circ} \mathrm{C}\right)$ under nitrogen stream $\left(\mathrm{N}_{2}, 99.995\right.$ $\%$ purity, Linde Gas) and the solvent was changed to isooctane (2,2,4-trimethyl pentane, HPLC grade, Scharlau). Finally, the sample was fractionated on a micro-column of silica (0.063-0.200 mm diameter, Merck). The first fraction containing alkanes was eluted with $2 \mathrm{~mL}$ of pentane (Ultra Resi-analyzedtype, JT Baker) and the second fraction containing PAHs was eluted with $3 \times 5 \mathrm{~mL}$ of pentane/dichloromethane $(65 / 35, v / v)$. Again, this fraction was concentrated under nitrogen stream and low heating and the solvent was changed in isooctane prior analysis.

\section{GC/MS}

In the case of GC/MS, the final volume was not a critical point due to the use of internal and "syringe" standards. An- alyte losses were evaluated by checking the internal standards recovery yields. "Syringe" standards were added to the sample and measured gravimetrically prior to the analysis by GC/MS for the quantification of the internal standards.

Quantitative analyses were performed using a gas chromatograph (HP model Series 6890) coupled to a quadrupole mass spectrometer (HP model 5973). Two different columns were used. First, for PAHs quantification, the capillary column was a $30 \mathrm{~m} \times 0.25 \mathrm{~mm}$ ID $\times 0.25 \mu \mathrm{m}$ film thickness Rxi17 (50\% of diphenyl and $50 \%$ of dimethyl-polysiloxane, Restek) in order to analyse some isomers classically coelutated in usual chromatographic conditions. One $\mu \mathrm{L}$ was injected into the GC (7683 autosampler injector, Agilent Technologies) in splitless mode (purge delay $=90 \mathrm{~s}$, purge flow $=60 \mathrm{~mL} \mathrm{~min}^{-1}, 25 \mathrm{psi}$ pulse during $90 \mathrm{~s}$ ). The injector temperature was $280^{\circ} \mathrm{C}$ and the oven temperature was 
maintained at $60^{\circ} \mathrm{C}$ during $2 \mathrm{~min}$, then programmed to increase from $60^{\circ} \mathrm{C}$ to $320^{\circ} \mathrm{C}$ at a rate of $10^{\circ} \mathrm{C} \mathrm{min}^{-1}$ and maintained at $320^{\circ} \mathrm{C}$ during $25 \mathrm{~min}$. Helium (He, 99.9996 $\%$ purity, Linde Gas) was used as carrier gas at the constant flow of $1.3 \mathrm{~mL} \mathrm{~min}^{-1}$. The interface temperature was kept at $290^{\circ} \mathrm{C}$ during analysis. Ionization was carried out by electron impact $(70 \mathrm{eV})$ and mass detection was performed in selected ion monitoring (SIM) mode (dwell time $=30$ $\mathrm{ms}$, electron multiplier voltage $=(1620 \pm 50) \mathrm{V}$, solvent delay $=5 \mathrm{~min}$ ). The ion molecular $\mathrm{m} / \mathrm{z}$ were chosen for native and perdeuterated PAHs.

PAH concentrations were measured using internal standard quantification and moreover, internal standards were quantified using "syringe" standards. This double quantification allowed the calculation of internal standard recovery yields and hence, to check that internal standards, and therefore native PAHs, were not lost during the analytical procedure. As described before in section 2.4.2, internal standards were added prior to the extraction in the ASE cell and "syringe" standards at the end of sample preparation before GC/MS. All the standards used in this study are presented in Table 2.

\section{Method evaluation}

For GC/MS, a calibration solution was prepared with nondeuterated PAH standard solution, internal standard solution and "syringe" standard solution for each type of analysis. This solution was injected before and after each sequence of analysis in order to calculate the PAH response factors with respect to the corresponding internal standards as well as the internal standard response factors with respect to the corresponding "syringe" standards. The response factor values range between 0.48 and 1.6 depending on the molecule. Variations of the response factors are within 2 to $6 \%$. The injections were carried out only if the conditions required for the analysis were fulfilled (good recovery yields of native and internal PAHs and response factors consistent with control monitoring), the calibration solution being also used to check and monitor the conditions of the chromatographic and detection systems.

Therefore, blanks filters and extraction blanks were extracted and analysed in order to check levels of PAHs during the application of analytical protocol (see Appendix S2 in Supplement).

The methodology for quantification of particulate-PAHs was validated by the application of our analytical procedure on SRM 1649a and SRM 1650b. Percentages of recovery yields for internal standards vary from $50 \%$ to $97 \%$ depending on the compounds (see Appendix S1 in Supplement).

\subsubsection{Determination of ${ }^{13} \mathrm{C} /{ }^{12} \mathrm{C}$ isotopic compositions of PAHs}

\section{Extraction and purification}

Extraction and purification were performed in the same conditions as those developed in the previous sections. Note only that neither internal standard nor syringe standard were used because molecular isotopic composition of a compound could be measured only if no coelution with other compounds appeared. Under our analytical conditions, native and perdeuterated PAHs were coeluted involving an external calibration of the GC/C/IRMS system.

\section{HPLC fractionation}

An additional purification step was required to eliminate the remaining aromatic unresolved complex mixture (UCM) that could interfere during the GC/C/IRMS analysis. As a consequence, after silica purification, the extract was concentrated in a volume of $200 \mu \mathrm{L}$ of isooctane and the aromatic fraction was fractionated by high performance liquid chromatography (HPLC) on aminosilane phase (Dyna$\max , 5 \mu \mathrm{m}, 250 \mathrm{~mm} \times 10 \mathrm{~mm}$ I.D., Varian) using the following solvent program: pentane $(100 \%)$ during $25 \mathrm{~min}$, then pentane/dichloromethane $(90 / 10, v / v)$ during $25 \mathrm{~min}$ and finally pentane $(100 \%)$ during $10 \mathrm{~min}$. The flowrate was $4 \mathrm{~mL} \mathrm{~min}^{-1}$. The HPLC fractionation based on ring number allowed the collection of five different fractions by detecting the UV signal at $254 \mathrm{~nm}$ : monoaromatic and diaromatic (naphthalenes and dibenzothiophenes for example), phenanthrenes, fluoranthene + pyrene, benz(a)anthracene + chrysene + pentaaromatics and hexaaromatics. In order to focus the fractionation on the native PAHs, HPLC fractionation was performed in the conditions described in a previous work by Guillon et al. (2013b). The objective was to collect only native PAHs and to eliminate remaining compounds by collecting fine fractions (Fig. 1) and reducing the time of collection to around the time of retention of studied compounds. After each fractionation, the integrity of each fraction was controlled by GC/MS and finally, the volume of reconcentration was optimized to perform isotopic composition analysis of the different fractions in accurate conditions.

\section{GC/MS for the validation of HPLC fractionation}

For the validation of HPLC fractionation, a classical method was applied on all the collected fractions. Analysis was performed by GC/MS using an HP model Series 5890 Gas Chromatograph coupled to an HP model 5972 mass-selective detector (quadrupole) (Agilent Technologies). The capillary column was a $30 \mathrm{~m} \times 0.25 \mathrm{~mm}$ ID $\times 0.25 \mu \mathrm{m}$ film thickness HP-5MS (Agilent Technologies). One $\mu \mathrm{L}$ was introduced into the GC via an auto-injector (HP model 7673, Agilent Technologies) in splitless mode injection (purge delay $=60 \mathrm{~s}$, 
purge flow $=60 \mathrm{~mL} \mathrm{~min}^{-1}, 25$ psi pulse during $\left.60 \mathrm{~s}\right)$. The injector temperature was $270^{\circ} \mathrm{C}$ and the oven temperature was maintained at $60^{\circ} \mathrm{C}$ during $2 \mathrm{~min}$, then programmed from $90^{\circ} \mathrm{C}$ to $330^{\circ} \mathrm{C}$ at a rate of $10^{\circ} \mathrm{C} \mathrm{min}^{-1}$ and maintained at $330^{\circ} \mathrm{C}$ during 5 min. Helium ( $99.9996 \%$ purity, Linde Gas) was used as carrier gas at the constant flow of $1.3 \mathrm{~mL} \mathrm{~min}^{-1}$. The interface temperature was kept at $290^{\circ} \mathrm{C}$ during analysis. Ionization was carried out by electron impact $(70 \mathrm{eV})$ and mass detection was performed in selected ion monitoring (SIM) mode (dwell time $=60 \mathrm{~ms}$, electron multiplier voltage $=(2900 \pm 50) \mathrm{V})$. The ion molecular $\mathrm{m} / z$ were chosen to native PAHs (compounds indexed with * in Table 2 ) and perdeuterated PAHs (only used in the case of the validation of analytical method with SRM 2975). This second GC/MS method was validated by the application of our analytical procedure on SRM 2975.

\section{GC/C/IRMS}

Measurements of molecular stable carbon isotopic composition are based on the elution of individual compounds through a gas chromatograph and their conversion to $\mathrm{CO}_{2}$ and $\mathrm{H}_{2} \mathrm{O}$ in a combustion furnace heated at $940^{\circ} \mathrm{C} . \mathrm{H}_{2} \mathrm{O}$ is then trapped via a Nafion membrane and purified $\mathrm{CO}_{2}$ is introduced into a magnetic mass spectrometer, continuously monitoring ions having mass ratio $(\mathrm{m} / \mathrm{z}) 44\left({ }^{12} \mathrm{C}^{16} \mathrm{O}_{2}\right), 45$ $\left({ }^{13} \mathrm{C}^{16} \mathrm{O}_{2}\right.$ and $\left.{ }^{12} \mathrm{C}^{17} \mathrm{O}^{16} \mathrm{O}\right)$ and $46\left({ }^{12} \mathrm{C}^{18} \mathrm{O}^{16} \mathrm{O},{ }^{13} \mathrm{C}^{17} \mathrm{O}^{16} \mathrm{O}\right.$ and ${ }^{12} \mathrm{C}^{17} \mathrm{O}_{2}$ ). The isotopic composition is then calculated using the ratio $44 / 45 \mathrm{~m} / \mathrm{z}$ and $44 / 46 \mathrm{~m} / \mathrm{z}$ for the correction of ${ }^{17} \mathrm{O}$ contribution to the $45 \mathrm{~m} / z$ signal. The isotopic ratio is reported in terms of $\delta^{13} \mathrm{C}$ and expressed in per mil (\%o), relative to the Vienna Pee Dee Belemnite standard (VPDB): $\delta^{13} \mathrm{C}=\left[\left({ }^{13} \mathrm{C} /{ }^{12} \mathrm{C}\right)_{\text {sample }} /\left({ }^{13} \mathrm{C} /{ }^{12} \mathrm{C}\right)_{\mathrm{VPDB}}-1\right] \times 10^{3}$.

Methodology of the determination of PAHs molecular isotopic compositions was validated and described in details elsewhere (Guillon, 2011; Guillon et al., 2013b). Briefly, stable-carbon isotopic analyses of individual PAHs were carried out by gas chromatography/combustion/isotope ratio mass spectrometry (GC/C/IRMS) using an HP 5890 Series II Plus gas chromatograph (Hewlett-Packard) interfaced via a $\mathrm{CuO}$ furnace $\left(940^{\circ} \mathrm{C}\right)$ and a hygroscopic membrane (Nafion) to a Delta Plus isotopic ratio mass spectrometer (Finnigan MAT Corporation). One $\mu \mathrm{L}$ to $3 \mu \mathrm{L}$ of solutions were injected into the GC in the splitless mode depending on the concentrations of studied analytes in the fractions. The GC oven temperature program was optimized to reduce PAHs coelutions with undesirable compounds. GC oven programs were used in the following conditions:

- Different fractions containing PAHs except pentaaromatics: $50^{\circ} \mathrm{C}(2 \mathrm{~min})$ to $300^{\circ} \mathrm{C}(15 \mathrm{~min})$ at a rate of $10^{\circ} \mathrm{C} \min ^{-1}$

- For pentaaromatics fraction: $50^{\circ} \mathrm{C}(2 \mathrm{~min})$ to $200^{\circ} \mathrm{C}$ at a rate of $10^{\circ} \mathrm{C} \mathrm{min}^{-1}$ and from $260^{\circ} \mathrm{C}$ to $300^{\circ} \mathrm{C}$ $(15 \mathrm{~min})$ at a rate of $2^{\circ} \mathrm{C} \mathrm{min}^{-1}$
The injector temperature was $270^{\circ} \mathrm{C}$. The carrier gas was helium ( $99.9996 \%$ purity, Linde Gas) (flow rate: $2 \mathrm{~mL} \mathrm{~min}^{-1}$ ). The capillary column was a $30 \mathrm{~m} \times 0.25 \mathrm{~mm}$ ID $\times 0.25 \mu \mathrm{m}$ film thickness HP-5MS (Agilent Technologies). For calculation purposes, $\mathrm{CO}_{2}$ reference gas $(99.995 \%$ purity, Linde Gas) was automatically introduced into the isotopic ratio mass spectrometer in a series of pulses at the beginning of each analysis.

Note that under our analytical conditions, benzo(k)fluoranthene (BkF), benzo(b)fluoranthene (BbF) and benzo(j)fluoranthene $(\mathrm{BjF})$ were coeluted and the isotopic composition determined and presented in this work concerned all these isomers (noted BFs).

\section{Method evaluation}

As there were no Standard Reference Materials on particulate-PAH isotopic compositions, it was decided to validate the integrity of analytical systems and to monitor the conditions of the chromatographic and detection systems for GC/C/IRMS analysis by using two different certified solutions: a first solution containing ${ }^{13} \mathrm{C} /{ }^{12} \mathrm{C}$ certified alkanes $(n$ $\mathrm{C}_{15}, n-\mathrm{C}_{20}, n-\mathrm{C}_{25}$, Chiron AS) and a second solution obtained dissolving ${ }^{13} \mathrm{C} /{ }^{12} \mathrm{C}$ certified $\mathrm{PAH}$ crystals in isooctane (dibenzonaphtothiophene, phenanthrene and coronene, Arndt Schimmelmann, University of Indiana, USA). Both solutions were analysed prior to any sequence of samples. Repeatability and reproducibility of the analytical method were regularly validated by measuring isotopic compositions of both certified solutions and confirmed by the analysis of native PAH solution (compounds indexed with * in Table 2) prior to any sequence of analysis. The reproducibility of the individual isotopic measurements is $\pm 0.50 \%$. Precision reported in this study is based on multiple analyses of each sample (at least three analyses). Therefore, as described by Guillon et al. (2013a), the analysis of PAH solutions from 20 to $450 \mathrm{ng} \mu \mathrm{L}^{-1}$ allowed determination of the operational linear range of the method and the limit of quantification, corresponding to the quantity of injected carbon required to measure signal amplitude of ion 44 peak up to $1 \mathrm{~V}$. Table 3 summarises the quantities of PAHs required to perform $\mathrm{GC} / \mathrm{C} / \mathrm{IRMS}$ analysis in accurate conditions.

\subsubsection{Application to standard reference materials}

Three standard reference materials were used for the validation of the full analytical procedure from extraction to quantification steps, as described in details in Appendix S1 (Supplement). Urban Dust (SRM 1649a) and Diesel exhaust (SRM 2975 and SRM 1650b) were purchased from NIST (Gaithersburg, MD, USA). As ambient particle samples, these materials are very complex containing a large panel of organic and inorganic compounds. SRM 1649a was collected during 12 months in the Washington DC area in 1976-1977 and represents a time-integrated sample of urban 
Table 3. Limits of quantification for the analysis of PAHs by GC/C/IRMS.

\begin{tabular}{lcc}
\hline & $\begin{array}{c}\text { Quantity of injected } \\
\text { carbon required to } \\
\text { obtain a 1 V signal }\end{array}$ & $\begin{array}{c}\text { Quantity of injected } \\
\text { compound required to } \\
\text { obtain a 1 V signal }\end{array}$ \\
\hline Phenanthrene & $77 \mathrm{ng}$ & $82 \mathrm{ng}$ \\
Fluoranthene & $100 \mathrm{ng}$ & $105 \mathrm{ng}$ \\
Pyrene & $90 \mathrm{ng}$ & $95 \mathrm{ng}$ \\
Benz(a)anthracene & $125 \mathrm{ng}$ & $132 \mathrm{ng}$ \\
Chrysene & $125 \mathrm{ng}$ & $132 \mathrm{ng}$ \\
Benzo(k)fluoranthene & $165 \mathrm{ng}$ & $173 \mathrm{ng}$ \\
Benzo(a)pyrene & $165 \mathrm{ng}$ & $173 \mathrm{ng}$ \\
Indeno(1,2,3-c,d)pyrene & $325 \mathrm{ng}$ & $340 \mathrm{ng}$ \\
Benzo(ghi)perylene & $500 \mathrm{ng}$ & $523 \mathrm{ng}$ \\
\hline
\end{tabular}

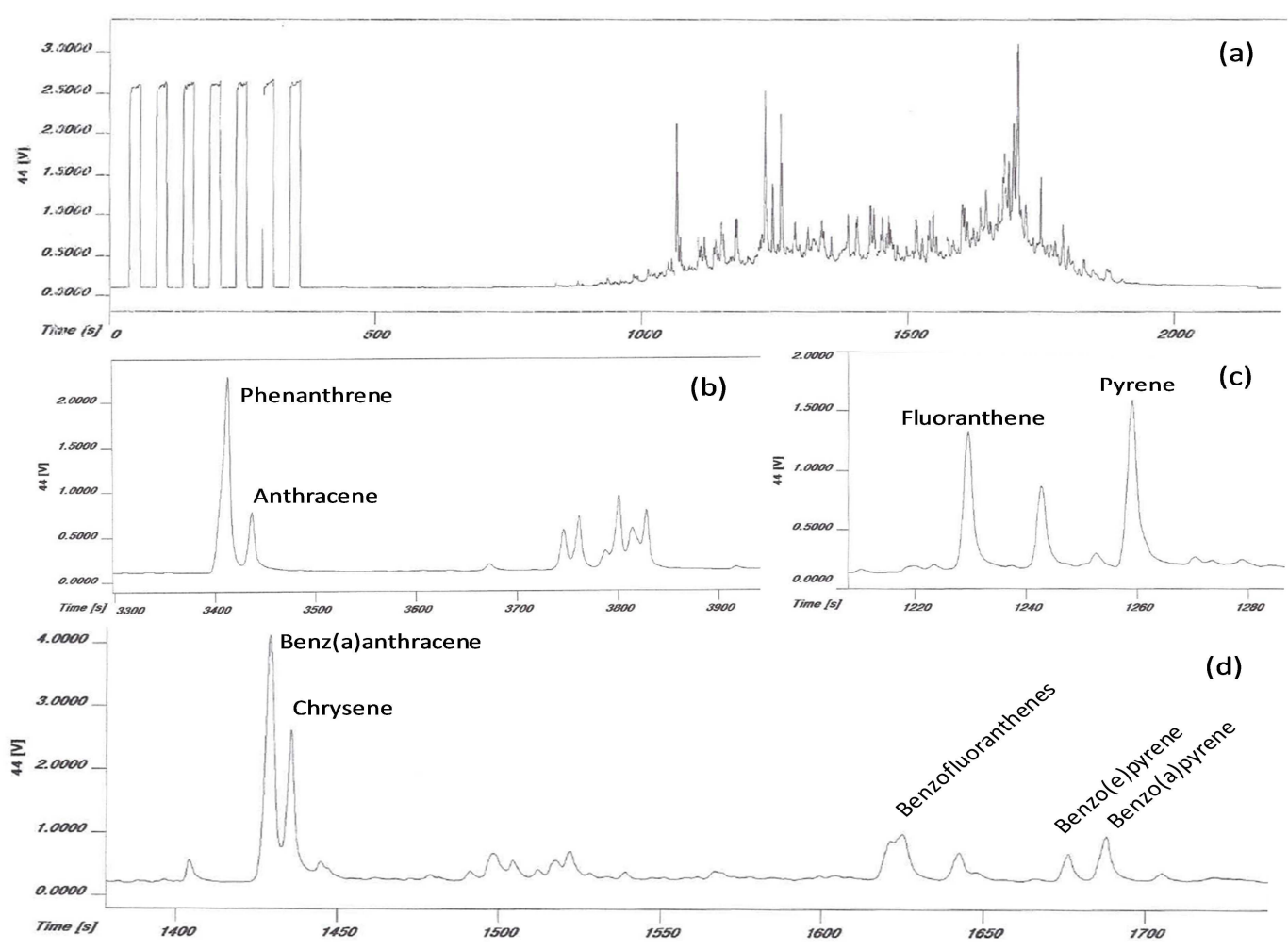

Fig. 1. GC/C/IRMS chromatograms of cork oak prior to HPLC fractionation (a) and after fractionation (b,c,d).

area (Wise and Watters, 2007). Four-cycle diesel engines operating in a large variety of conditions during $200 \mathrm{~h}$ allowed the collection of SRM $1650 \mathrm{~b}$ which was representative of heavy-duty diesel engine emissions (Wise and Watters, 2006). SRM 2975 was collected from a filtering system designed for an industrial diesel-powered forklift (Wise and Watters, 2009). The certified value for total carbon (organic and elemental) is $(0.1768 \pm 0.0019) \mathrm{g} / \mathrm{g}$ for SRM 1649a particles. This value was not available for Diesel exhausts. These sets of particles are certified for PAH concentrations by NIST.
Analytical protocol of PAH quantification was applied on SRM in order to certify the correct extraction of PAH in the sequence of wood particle extraction and to validate the quantification of 31 PAHs by GC/MS. Recovery yields of internal standard range from $(46 \pm 13) \%$ to $(69 \pm 12) \%$, from $(59 \pm 15) \%$ to $(84 \pm 12) \%$ and from $47 \%$ to $91 \%$ for SRM 2975, SRM 1650b and SRM1649a, respectively (Fig. S1 in the Supplement). Uncertainties vary between $10 \%$ and $15 \%$. PAH concentrations determined in this study for the different standard materials coincide well with reference and certified values reported in the literature (Table S1 and Fig. S2). 
Table 4. $\mathrm{PAH}$ concentrations in $\mathrm{PM}_{2.5}$ from wood combustion ( $\mathrm{mg} \mathrm{g}^{-1}$ of $\mathrm{OC}$ ).

\begin{tabular}{|c|c|c|c|c|c|c|c|c|c|c|c|}
\hline & \multicolumn{7}{|c|}{ HARDWOOD } & \multicolumn{3}{|c|}{ SOFTWOOD } & \multirow{2}{*}{$\begin{array}{r}\text { COAL } \\
\begin{array}{r}\text { Eucalyptus } \\
\text { Moroccan coal }\end{array}\end{array}$} \\
\hline & $\begin{array}{r}\text { Cork oak } \\
\text { twigs } 1\end{array}$ & Rosemary & $\begin{array}{r}\text { Green } \\
\text { oak }\end{array}$ & $\begin{array}{r}\text { Kermès } \\
\text { oak }\end{array}$ & $\begin{array}{r}\text { Cork } \\
\text { oak }\end{array}$ & $\begin{array}{r}\text { Mediterranean } \\
\text { False-Brome }\end{array}$ & $\begin{array}{r}\text { Heather } \\
1\end{array}$ & $\begin{array}{r}\text { Alep } \\
\text { pine } 1\end{array}$ & $\begin{array}{r}\text { Alep } \\
\text { pine } 2\end{array}$ & $\begin{array}{r}\text { Cypress } \\
1\end{array}$ & \\
\hline Combustion condition & smold & Flame & flame & flame & flame & flame & flame & flame & flame & smold & smold \\
\hline Naph & 0.074 & 0.001 & 0.004 & 0.017 & 0.103 & n.d. & 5.747 & 0.006 & 0.824 & 0.026 & 1.072 \\
\hline Acy & 0.038 & n.d. & 0.015 & n.d. & n.d. & 0.012 & 0.004 & 0.093 & 0.094 & 0.078 & 0.004 \\
\hline Ace & 0.004 & 0.004 & 0.003 & n.d. & 0.005 & 0.001 & n.d. & 0.016 & 0.023 & 0.012 & n.d. \\
\hline $\mathrm{Fl}$ & 0.073 & 0.046 & 0.034 & 0.010 & 0.014 & 0.016 & 0.019 & 0.083 & 0.122 & 0.110 & 0.003 \\
\hline Phen & 1.385 & 1.164 & 0.564 & 0.188 & 0.179 & 0.236 & 0.449 & 1.286 & 2.971 & 0.524 & 0.047 \\
\hline Anth & 0.323 & 0.226 & 0.132 & 0.021 & n.d. & 0.043 & 0.072 & 0.212 & 0.479 & 0.123 & n.d. \\
\hline DBT & 0.003 & 0.003 & 0.002 & n.d. & n.d. & n.d. & n.d. & 0.006 & 0.005 & 0.002 & n.d. \\
\hline Fluo & 1.340 & 1.661 & 0.745 & 0.589 & 0.452 & 0.433 & 0.691 & 1.323 & 1.528 & 0.259 & 0.246 \\
\hline Pyr & 1.450 & 1.771 & 0.778 & 0.655 & 0.530 & 0.427 & 0.737 & 1.442 & 1.548 & 0.221 & 0.280 \\
\hline BghiF & 0.248 & 0.360 & 0.151 & 0.222 & 0.156 & 0.088 & 0.136 & 0.307 & 0.269 & 0.036 & 0.380 \\
\hline CcdP & 0.392 & 0.670 & 0.218 & 0.293 & 0.215 & 0.125 & 0.213 & 0.480 & 0.431 & 0.059 & 0.579 \\
\hline $\mathrm{BcP}$ & 0.103 & 0.181 & 0.056 & 0.086 & 0.057 & 0.032 & 0.053 & 0.111 & 0.145 & 0.013 & 0.096 \\
\hline $\mathrm{BaA}$ & 0.410 & 0.777 & 0.214 & 0.340 & 0.285 & 0.137 & 0.250 & 0.377 & 0.454 & 0.059 & 0.634 \\
\hline Chrys & 0.437 & 1.146 & 0.278 & 0.514 & 0.380 & 0.143 & 0.343 & 0.392 & 0.547 & 0.075 & 0.795 \\
\hline $\mathrm{BbF}$ & 0.206 & 0.306 & 0.126 & 0.229 & 0.188 & 0.090 & 0.135 & 0.218 & 0.255 & 0.032 & 0.511 \\
\hline $\mathrm{BkF}$ & 0.115 & 0.174 & 0.062 & 0.107 & 0.086 & 0.045 & 0.067 & 0.128 & 0.129 & 0.014 & 0.249 \\
\hline $\mathrm{BjF}$ & 0.169 & 0.278 & 0.092 & 0.165 & 0.118 & 0.061 & 0.105 & 0.183 & 0.203 & 0.022 & 0.336 \\
\hline $\mathrm{BaF}$ & 0.119 & 0.184 & 0.068 & 0.113 & 0.091 & 0.054 & 0.071 & 0.115 & 0.141 & 0.018 & 0.208 \\
\hline $\mathrm{BeP}$ & 0.147 & 0.223 & 0.094 & 0.174 & 0.131 & 0.056 & 0.101 & 0.161 & 0.175 & 0.023 & 0.389 \\
\hline $\mathrm{BaP}$ & 0.292 & 0.431 & 0.164 & 0.271 & 0.208 & 0.102 & 0.176 & 0.318 & 0.307 & 0.035 & 0.581 \\
\hline Per & 0.049 & 0.068 & 0.028 & 0.045 & 0.035 & 0.018 & 0.028 & 0.053 & 0.051 & 0.006 & 0.092 \\
\hline DBacA & 0.021 & 0.031 & 0.015 & 0.020 & n.d. & 0.009 & 0.013 & 0.022 & 0.023 & 0.003 & 0.032 \\
\hline IP & 0.152 & 0.235 & 0.093 & 0.151 & 0.092 & 0.058 & 0.090 & 0.184 & 0.165 & 0.020 & 0.281 \\
\hline DBahA & 0.022 & 0.037 & 0.015 & 0.020 & n.d. & 0.007 & 0.013 & 0.021 & 0.023 & 0.003 & 0.034 \\
\hline BghiP & 0.159 & 0.248 & 0.109 & 0.167 & 0.110 & 0.056 & 0.105 & 0.213 & 0.181 & 0.023 & 0.389 \\
\hline Antha & 0.094 & 0.138 & 0.067 & 0.069 & 0.053 & 0.034 & 0.059 & 0.113 & 0.104 & 0.014 & 0.116 \\
\hline DBbkF & 0.018 & 0.036 & 0.013 & 0.008 & n.d. & 0.011 & 0.012 & 0.026 & 0.025 & 0.004 & n.d. \\
\hline DalP & 0.043 & 0.064 & 0.024 & 0.036 & n.d. & 0.018 & 0.034 & 0.043 & 0.048 & 0.002 & 0.054 \\
\hline DaeP & 0.020 & 0.026 & 0.012 & n.d. & n.d. & 0.006 & 0.008 & 0.021 & 0.023 & 0.002 & n.d. \\
\hline Cor & 0.073 & 0.135 & 0.056 & 0.117 & 0.117 & 0.029 & 0.061 & 0.125 & 0.096 & 0.013 & 0.199 \\
\hline DahP & n.d. & n.d. & n.d. & n.d. & n.d. & n.d. & n.d. & n.d. & 0.006 & n.d. & n.d. \\
\hline$\Sigma \mathrm{PAH}_{\text {part }}$ & 7.98 & 10.62 & 4.23 & 4.63 & 3.60 & 2.35 & 9.79 & 8.08 & 11.40 & 1.83 & 7.61 \\
\hline $\mathrm{OC}\left(\mu \mathrm{g} \mathrm{m}^{-3}\right)$ & 3902 & 1318 & 3395 & 515 & 304 & 2298 & 1126 & 2923 & 3433 & 12416 & 121 \\
\hline $\mathrm{EC}\left(\mu \mathrm{g} \mathrm{m}^{-3}\right)$ & 67 & 165 & 188 & 57 & 16 & 22 & 174 & 223 & 226 & 390 & $<1$ \\
\hline
\end{tabular}

n.d. $=$ non detected compounds

numbers are the identification numbers of samples

Concerning the quantification of PAHs extracted from SRM $1650 \mathrm{~b}$, some values are lower than certified ones but this gap could be explained by the conditions of extraction which were softer than the ones used for the certification of this standard material. This is mainly due to the change of the extraction setup (from ASE 200 to ASE 350) during this work, that may allow higher extraction yields performed at the same $T$ and $P$ conditions.

The results obtained on SRM 2975, SRM 1650b and SRM 1649a show the good reproducibility and repeatability of our analytical procedure. Analyses were therefore validated and allow the determination of the concentrations and the isotopic compositions of PAHs of generated particles.

Concerning the validation of ${ }^{13} \mathrm{C}$ molecular isotopic measurements, the methodology developed in this work was first validated on model particles: PAH-bounded silica particles were extracted by PFE; extracts were purified using HPLC fractionation and injected in GC/C/IRMS. Isotopic compositions of PAHs, measured all along the procedure, were found to remain constant within uncertainties (Guillon et al., 2013b).

\section{Results and discussion}

\subsection{Molecular approach}

\subsubsection{Concentrations of PAHs}

Concentrations of 31 PAHs were determined in $\mathrm{PM}_{2.5}$ sampled during wood combustion experiments. Internal standard recovery yields range from 30 to $97 \%$. Note that the lowest values corresponded to DBT-d8 recovery yield which is a low molecular weight compound and may be lost easily during evaporation steps. Because of the method of quantification, native PAHs and internal standards are affected by the same physico-chemical processes during the various steps of the analytical procedure. The use of internal standards allows 
us to correct the potential losses of native PAHs. Table 4 presents the concentrations of particulate-PAHs sampled in the chamber during the combustion of wood species compared to the global concentrations of organic carbon (OC). Due to the non-availability of OC data, concentrations are not reported for four experiments: cork oak twigs 2 , juniper tree, heather 2 and cypress 2 .

First, PAH concentrations depend on the compounds and on the wood species. Particulate-PAH concentrations $\left(\Sigma \mathrm{PAH}_{\text {part }}\right)$ range from 1.83 to $11.40 \mathrm{mg} \mathrm{g}^{-1} \mathrm{OC}$ for Cypress 1 and alep pine 2 respectively, meaning a variation of about one order of magnitude between wood species. These values coincide well with PAH concentrations reported in the literature concerning controlled wood burnings for the characterization of particulate emissions (Fine et al., 2001, 2002; Schmidl et al., 2008; Gonçalves et al., 2010) but slightly lower than those reported by Alves et al. (2010).

Therefore, levels of PAH concentrations are significantly different within the same wood family. For example, combustion of oak woods generate PAH levels from 3.6 to $7.98 \mathrm{mg} \mathrm{g}^{-1}$ of OC. It could be explained by the adaptation of the different species of oaks to the Mediterranean climate (humidity, temperature). Concerning cork oak burnings, the nature of wood affects the level of PAH concentrations with higher concentration emissions, for the combustion of twigs.

In addition, the type of wood (hardwood vs. softwood) is not correlated with the levels of PAH concentrations. This tendency is not consistent with the previous results of Gonçalves et al. (2010), who differentiate the softwood Pinus Pinaster combustion $\left(\Sigma \mathrm{PAH} \mathrm{H}_{\text {part }}=75.5 \mathrm{mg} \mathrm{g}^{-1}\right.$ OC) from three different hardwood combustions $\left(\Sigma \mathrm{PAH} \mathrm{H}_{\text {part }}\right.$ $<10 \mathrm{mg} \mathrm{g}^{-1} \mathrm{OC}$ ). On the contrary, our work is consistent with that reported by Fine et al. (2001, 2002), who did not significantly differentiate PAH concentrations between hardwood and softwood combustions from North-eastern and Southern United States.

Considering the concentrations, PAH repartitions for the different studied woods are quite similar: fluoranthene and pyrene are the dominant compounds for all woods, especially for softwoods. This tendency has already been reported in the literature (Fine et al., 2001, 2002; Alves et al., 2010; Gonçalves et al., 2010), fluoranthene and pyrene being considered as characteristic of $\mathrm{PM}_{2.5}$ from wood combustion. Alves et al. (2010) reported a different molecular profile for $\mathrm{PM}_{10}$ with benz(a)anthracene as the most abundant PAH.

\subsubsection{Molecular fingerprints of particulate-PAHs}

Different tools for source apportionment may be used to differentiate emissions from combustion of wood species. The determination of molecular fingerprints was performed on all the different woods presented in Table 1. Note that as no OC values were available for cork oak-twigs 2 , juniper tree, cypress 2 and heather 2, these last four wood species were only discussed in that section. Figure 2 presents PAHs molecu- lar repartitions of the different woods studied here. Percentages of contribution of each PAH were determined considering the total of particulate PAHs from $m / z 228$ to 302 (from benz(a)anthracene to dibenzoperylenes). The choice of such high molecular weight compounds was made as they are mostly present on atmospheric particulate matter of interest in this study (Odabasi et al., 1999; Ré-Poppi and SantiagoSilva, 2005).

No significant particularities could be underlined meaning that PAH molecular profiles are conserved for the variety of all wood species. Considering Fig. 2 only, benz(a)anthracene and chrysene represent the dominant contributions in the sum of particulate-PAHs (from BaA to DahP) followed by benzo(a)pyrene. Benz(a)anthracene and chrysene contributions vary from 12.9 to $17.1 \%$ and from 14.5 to $25.4 \%$ respectively. Note that preponderance of both compounds was already reported in the literature as molecular markers of wood combustion (Marchand et al., 2004; Ravindra et al., 2008). Our results confirm the interest of chrysene measurements in source assessment methodologies.

The main differences concern compounds with low concentrations such as perylene, DBacA, DBahA, DBbkF, DalP, DaeP and DahP meaning that these compounds could not be used as molecular tracers because of too low concentrations in ambient samples. Previous works reported the interest of molecular fingerprints in order to differentiate PAH sources (Sun et al., 2003; Zhang et al., 2009; El Haddad et al., 2011) and some models of source apportionment are based on these measurements to determine the origins of particulate matter. In this study, we show that the use of a single molecular fingerprint based on PAH concentrations could traduce the origin of Mediterranean wood burnings regardless of the wood species because of the similarities of molecular fingerprints of the eleven woods, as expected. In addition, by comparing (1) and (2) samples for cork oak, heather and cypress species, it is confirmed that there is no impact of combustion conditions.

The application of the methodology for determining PAH molecular fingerprints on the results of Fine et al. (2001, 2002) by choosing the commonly measured compounds reveals some similarities and some particularities for the large variety of studied species (Table 5). This molecular approach shows that some compounds may allow differentiating combustion of woods from North America and the Mediterranean Basin. As shown in Table 5, BkF, BjF, IP, BghiP, Antha and Cor contributions to the sum of PAH concentrations (from $\mathrm{BaA}$ to Cor) are significantly different between the two sets of wood burnings. Note that wood species are characteristic from the two areas and that these values are calculated as a mix of both softwoods and hardwoods, meaning that whatever the type of wood, the molecular signature is conserved from a region. Such observations confirms the importance of the choice of fingerprints in source apportionment models depending on the area of interest and the necessity to study a large panel of particulate-PAHs characteristic 
Table 5. PAH molecular fingerprints of wood combustion emissions from USA and Mediterranean Basin.

\begin{tabular}{lcc}
\hline $\begin{array}{l}\text { PAH contribution } \\
(\%)\end{array}$ & $\begin{array}{c}\text { USA woods } \\
\text { Fine et al. (2001, 2002) }\end{array}$ & $\begin{array}{c}\text { Mediterranean Woods } \\
\text { (this study) }\end{array}$ \\
\cline { 2 - 3 } & Min-Max & Min-Max \\
\hline BaA & $13.4-19.4$ & $13.8-18.5$ \\
Chrys & $13.7-20.3$ & $15.8-27.3$ \\
BbF & $6.3-10.4$ & $7.3-11.1$ \\
$\mathrm{BkF}$ & $8.0-11.3$ & $3.3-5.4$ \\
$\mathrm{BjF}$ & $2.4-4.6$ & $5.3-7.5$ \\
$\mathrm{BeP}$ & $4.8-6.6$ & $5.3-8.4$ \\
$\mathrm{BaP}$ & $8.9-11.4$ & $9.6-12.8$ \\
Per & $1.0-1.8$ & $1.5-2.2$ \\
$\mathrm{IP}$ & $6.9-11.8$ & $5.1-7.4$ \\
$\mathrm{BghiP}$ & $4.0-5.3$ & $5.7-8.6$ \\
Antha & $0.9-2.0$ & $2.5-5.9$ \\
DahA & $0.4-0.9$ & $0.0-1.1$ \\
Cor & $8.6-18.7$ & $2.8-6.5$ \\
\hline
\end{tabular}

of sampling sites. Nevertheless, the conservation of molecular fingerprints does not allow the differentiation of different kinds of wood burnings in the same area, showing the necessity to use other methodologies of source apportionment regarding wood species from the United States of America and from the Mediterranean Basin.

\subsubsection{Diagnostic ratios}

Molecular approach of source apportionment may be based on the use of molecular fingerprints as described in the previous section but also on the use of molecular diagnostic ratios. They are largely used in the literature for source tracking (Yang and Chen, 2004; Li et al., 2009, 2010). This methodology is based on the measurements of PAH concentrations and the determination of concentration ratios which may be specific to each origin and considered as constant during the atmospheric transport of particulate matter. Note that diagnostic ratios could nevertheless be affected by the variation of environmental conditions (photochemistry, oxidative processes, mixing of air masses...).

Table 6 presents diagnostic ratios determined in this work. First, some diagnostic ratios are very similar for the different species, such as $[$ Phen $] /([$ Phen $]+[$ Anth $])$ and $[$ Fluo $] /([$ Fluo $]+[\mathrm{Pyr}])$. On the contrary, some molecular ratios allow differentiation of some varieties of wood species. For example, $[\mathrm{IP}] /([\mathrm{IP}]+[\mathrm{BghiP}]),[\mathrm{BaA}] /[\mathrm{BaP}]$, $[\mathrm{BghiP}] /[\mathrm{IP}]$ and $[\mathrm{Pyr}] /[\mathrm{BaP}]$ are significantly different for eucalyptus Moroccan Coal than for other woods. Note that eucalyptus Moroccan Coal is a coal and particulate-PAHs are not considered as wood burning signatures, contrary to other materials studied in this work. Moreover, $[\mathrm{BaA}] /[\mathrm{BaP}]$ and $[\mathrm{Pyr}] /[\mathrm{BaP}]$ could be used for the apportionment of cypress trees. Despite of a large range of variations of diagnostic ratios, no tendency is observed concerning concerning both softwood and hardwood families. Nevertheless, variations of diagnostic ratios are not sufficient to differentiate all woods, meaning that others factors may involve variations of $\mathrm{PAH}$ ratios such as conditions of combustion, temperature, elemental carbon normalization...

Concerning biomass burning, several reference values of diagnostic ratios are reported in the literature: Ravindra et al. (2008) demonstrates that $[\mathrm{BaP}] /[\mathrm{BghiP}]$ values up to 1.25 and $[\mathrm{IP}] /([\mathrm{IP}]+[\mathrm{BghiP}])$ close to 0.62 correspond to PAHs emitted from wood burning. $\mathrm{Li}$ and Kamens (1993) determined reference values between 1 and 1.5 for $[\mathrm{BaA}] /[\mathrm{BaP}]$ and around 0.8 for $[\mathrm{BghiP}] /[\mathrm{IP}]$. [Phen $] /([\mathrm{Phen}]+[$ Anth $])$ value is evaluated at $0.84 \pm 0.16$ by Galarneau (2008).The different diagnostic ratios measured in this study are consistent with these reference diagnostic ratios except for $[\mathrm{IP}] /([\mathrm{IP}]+[\mathrm{BghiP}])$, $[\mathrm{BghiP}] /[\mathrm{IP}]$ and $[$ Fluo $] /([$ Fluo $]+[\mathrm{Pyr}])$. Thus, concerning $[\mathrm{IP}] /([\mathrm{IP}]+[\mathrm{BghiP}])$ and $[\mathrm{BghiP}] /[\mathrm{IP}]$, diagnostic ratios from this study are respectively lower and higher than reported reference values. Nevertheless, $[\mathrm{IP}] /([\mathrm{IP}]+[\mathrm{BghiP}])$ varies in a large range depending on the sources. What is more, the values reported by Ravindra et al. (2008) for Diesel exhaust, coal and wood combustion are in the range of those measured for Diesel exhaust (0.35-0.7) reported by Rogge et al. (1993). The variation of combustion conditions in the different works and the impact of physico-chemical processes on diagnostic ratios during the transport of particulate matter may possibly affect the reference values explaining the gap observed in several studies performed in different conditions. $[$ Fluo $] /([$ Fluo $]+[$ Pyr $])$ range between 0.45 and 0.50 in this study but these values also correspond to gasoline exhaust diagnostic ratios reported by Dallarosa et al. (2005) confirming the limitation of this method for source apportionment. Another example is the $[\mathrm{BaA}] /[\mathrm{BaP}]$ ratio for which values for the different woods studied in this work are consistent with 
Table 6. PAH diagnostic ratios of wood combustion.

\begin{tabular}{|c|c|c|c|c|c|c|c|c|}
\hline Wood species & $\begin{array}{l}{[\text { Phen }] /} \\
{[\text { Phen }]+[\text { Anth }]}\end{array}$ & $\begin{array}{l}\text { [Fluo }] / \\
{[\text { Fluo }]+[\text { Pyr }]}\end{array}$ & $\begin{array}{l}{[\mathrm{IP}] /} \\
{[\mathrm{IP}]+[\mathrm{BghiP}]}\end{array}$ & {$[\mathrm{BaA}] /[\mathrm{BaP}]$} & {$[\mathrm{BghiP}] /[\mathrm{IP}]$} & {$[\mathrm{Pyr}] /[\mathrm{BaP}]$} & {$[\mathrm{BaP}] /[\mathrm{BghiP}]$} & \\
\hline Cork oak-twigs 1 & 0.81 & 0.48 & 0.49 & 1.40 & 1.05 & 4.97 & 1.83 & \\
\hline Cork oak-twigs 2 & 0.79 & 0.50 & 0.49 & 1.58 & 1.02 & 4.32 & 2.01 & \\
\hline Juniper Tree* & 0.73 & 0.48 & 0.49 & 1.80 & 1.05 & 3.81 & 1.69 & \\
\hline Rosemary & 0.84 & 0.48 & 0.49 & 1.80 & 1.06 & 4.11 & 1.74 & \\
\hline Alep Pine $1^{*}$ & 0.86 & 0.48 & 0.46 & 1.18 & 1.16 & 4.54 & 1.49 & \\
\hline Green oak & 0.81 & 0.49 & 0.46 & 1.31 & 1.17 & 4.74 & 1.51 & \\
\hline "kermès" oak & 0.90 & 0.47 & 0.47 & 1.26 & 1.11 & 2.42 & 1.63 & \\
\hline Cork oak & - & 0.46 & 0.46 & 1.37 & 1.20 & 2.55 & 1.90 & $\begin{array}{l}\text { this study } \\
\text { (Mediterranean area) }\end{array}$ \\
\hline Cypress $1^{*}$ & 0.81 & 0.54 & 0.47 & 1.66 & 1.13 & 6.25 & 1.57 & \\
\hline Cypress $2 *$ & 0.74 & 0.50 & 0.48 & 1.64 & 1.09 & 5.04 & 1.81 & \\
\hline Mediterranean False-Brome & 0.85 & 0.50 & 0.51 & 1.34 & 0.97 & 4.17 & 1.82 & \\
\hline Eucalyptus Moroccan coal & - & 0.47 & 0.42 & 1.09 & 1.38 & 0.48 & 1.49 & \\
\hline Heather 1 & 0.86 & 0.48 & 0.46 & 1.42 & 1.16 & 4.20 & 1.68 & \\
\hline Heather 2 & 0.72 & 0.50 & 0.49 & 1.62 & 1.02 & 4.31 & 1.73 & \\
\hline Alep pine $2 *$ & 0.86 & 0.50 & 0.48 & 1.48 & 1.10 & 5.04 & 1.69 & \\
\hline Eucalyptus globulus & 0.97 & 0.51 & 0.57 & 1.26 & 0.76 & 4.17 & 1.62 & \\
\hline Pinus pinaster* & 0.85 & 0.64 & 0.35 & 1.18 & 1.89 & 1.53 & 0.73 & $\begin{array}{l}\text { Gonçalves et al. (2008) } \\
\text { (Portugal) }\end{array}$ \\
\hline Quercus suber & 0.28 & 0.78 & 0.10 & 1.98 & 9.47 & 8.84 & 0.25 & \\
\hline Acacia longifolia & - & 0.54 & 0.28 & 1.46 & 2.60 & 2.41 & 0.22 & \\
\hline Pine wood* & 0.90 & 0.44 & 0.21 & 1.02 & 3.68 & 2.56 & 1.94 & $\begin{array}{l}\text { Rogge et al. (1998) } \\
\text { (USA) }\end{array}$ \\
\hline Oak wood & 0.84 & 0.43 & 0.27 & 0.91 & 2.77 & 2.30 & 1.77 & \\
\hline Red maple & - & 0.43 & 0.71 & 1.61 & 0.40 & 3.41 & 1.88 & \\
\hline Red oak & - & 0.45 & 0.61 & 1.60 & 0.64 & 4.07 & 2.20 & \\
\hline Yellow poplar & 0.83 & 0.46 & 0.59 & 1.45 & 0.70 & 3.55 & 2.02 & \\
\hline White ash & - & 0.43 & 0.63 & 1.18 & 0.60 & 2.40 & 2.13 & $\begin{array}{l}\text { Fine et al. }(2001,2002) \\
\text { (USA) }\end{array}$ \\
\hline White pine* & 0.83 & 0.54 & 0.64 & 1.41 & 0.55 & 5.06 & 2.53 & \\
\hline Hemlock* & 0.78 & 0.48 & 0.65 & 1.85 & 0.55 & 4.41 & 2.60 & \\
\hline Balsam fir* & 0.78 & 0.48 & 0.63 & 1.81 & 0.58 & 4.43 & 2.26 & \\
\hline Loblolly pine* & 0.86 & 0.52 & 0.67 & 1.64 & 0.48 & 5.36 & 2.47 & \\
\hline Slash pine* & 0.74 & 0.51 & 0.71 & 1.67 & 0.40 & 9.00 & 1.96 & \\
\hline Bamboo & 0.70 & 0.53 & - & 1.00 & - & 1.80 & - & $\begin{array}{l}\text { Oros et al. (2006) } \\
\text { (Malaysia) }\end{array}$ \\
\hline Sugarcane & 0.77 & 0.53 & - & 2.15 & - & 5.85 & - & \\
\hline Chestnut oak & 0.83 & 0.51 & - & 0.85 & - & 1.08 & - & \\
\hline v Chinese evergreen chinkapin & 0.71 & 0.50 & - & 0.95 & - & 1.24 & - & $\begin{array}{l}\text { Wang et al. (2009) } \\
\text { (China) }\end{array}$ \\
\hline Common aporusa** & 0.76 & 0.60 & - & 0.77 & - & 2.70 & - & \\
\hline Cape jasmine** & 0.71 & 0.56 & - & 0.69 & - & 1.33 & - & \\
\hline Moaning myrtle** & 0.72 & 0.54 & - & 0.93 & - & 1.60 & - & \\
\hline
\end{tabular}

*Softwoods

** Shrubs

numbers are the identification numbers of samples

the reference value (Li and Kamens, 1993) and with the values reported for other wood combustion studies (Table 6) but also similar to the diagnostic ratios of Diesel exhaust (0.91.7) reported by the same study of Li and Kamens (1993).

The application of the molecular approach to data sets from literature is difficult but allows the differentiation of wood species from several areas such as North American, Asian or European woods despite of previously noticed differences from reference values. Some diagnostic ratios were calculated by using PAH concentrations reported in previous studies of wood burnings from these different areas and are presented in Table 6. Depending on the compounds, some diagnostic ratios, such as [Fluo $] /([$ Fluo $]+[\mathrm{Pyr}]),[\mathrm{Pyr}] /[\mathrm{BaP}]$ and $[\mathrm{BaP}] /[\mathrm{BghiP}]$, are constant in the range of $0.4-0.6$, up to 1.24 and up to 1.49 respectively, independent of the wood and the area of interest, except for the results reported by Gonçalves et al. (2008). For most of the studied PAH ratios, measurements are not in good agreement because of either high variations of diagnostic ratios or different conditions of sampling. Consequently, the diagnostic ratios of this study are significantly different despite the fact that the area of interest was similar (Mediterranean Basin).

Moreover, $[\mathrm{Pyr}] /[\mathrm{BaP}]$ is constant except for eucalyptus Moroccan coal the value of which is lower than any reported values. This may be due to the nature of burned material (coal vs. dried wood) and this is observed considering $[\mathrm{BaA}] /[\mathrm{BaP}],[\mathrm{BghiP}] /[\mathrm{IP}]$ and $[\mathrm{IP}] /([\mathrm{IP}]+[\mathrm{BghiP}])$. In the case of $[\mathrm{Pyr}] /[\mathrm{BaP}]$, the trend is the same as for $[$ Phen $] /([$ Phen $]+[$ Anth $])$ and $[\mathrm{BaA}] /[\mathrm{BaP}]$ with lower ratios for Asian woods than for American and European 
Table 7. Molecular isotopic compositions of PAHs.

\begin{tabular}{|c|c|c|c|c|c|c|c|c|}
\hline$\delta^{13} \mathrm{C}(\% \circ)$ & Cork oaktwigs (1) & Cork oaktwigs (2) & Juniper Tree & Rosemary & Alep pine (1) & Alep pine (2) & Heather (1) & Heather (2) \\
\hline Phen & $-29.7 \pm 0.2$ & $-27.6 \pm 0.1$ & - & $-26.3 \pm 0.1$ & $-25.3 \pm 0.2$ & $-25.5 \pm 0.3$ & $-24.9 \pm 0.1$ & $-24.4 \pm 0.3$ \\
\hline Fluo & $-30.3 \pm 0.9$ & $-28.7 \pm 0.1$ & $-30.0 \pm 0.4$ & $-27.3 \pm 0.4$ & $-26.3 \pm 0.1$ & $-26.8 \pm 0.3$ & $-25.8 \pm 0.5$ & $-25.8 \pm 0.3$ \\
\hline Pyr & $-29.4 \pm 0.4$ & $-28.4 \pm 0.1$ & $-27.8 \pm 0.2$ & $-26.9 \pm 0.2$ & $-26.3 \pm 0.2$ & $-26.0 \pm 0.2$ & $-24.7 \pm 0.2$ & $-25.0 \pm 0.3$ \\
\hline $\mathrm{BaA}$ & $-28.9 \pm 0.2$ & $-28.1 \pm 0.1$ & $-27.1 \pm 0.3$ & $-26.9 \pm 0.4$ & - & $-25.9 \pm 0.4$ & $-24.4 \pm 0.2$ & $-24.1 \pm 0.2$ \\
\hline Chrys & $-29.0 \pm 0.1$ & $-30.0 \pm 0.3$ & $-27.7 \pm 0.8$ & $-26.6 \pm 0.6$ & - & $-26.7 \pm 0.6$ & $-25.0 \pm 0.3$ & $-24.8 \pm 0.2$ \\
\hline $\mathrm{BkF}$ & $-29.9 \pm 0.1$ & $-29.6 \pm 0.3$ & - & $-27.5 \pm 0.2$ & - & $-26.6 \pm 0.1$ & $-25.7 \pm 0.4$ & $-25.0 \pm 0.1$ \\
\hline $\mathrm{BeP}$ & $-29.5 \pm 0.3$ & $-28.7 \pm 0.1$ & - & $-27.3 \pm 0.3$ & - & $-25.7 \pm 0.2$ & $-25.1 \pm 0.5$ & $-24.9 \pm 0.9$ \\
\hline $\mathrm{BaP}$ & $-29.8 \pm 0.1$ & $-29.7 \pm 0.5$ & - & $-27.6 \pm 0.4$ & - & $-26.4 \pm 0.2$ & $-25.5 \pm 0.4$ & $-24.6 \pm 0.6$ \\
\hline IP & $-29.9 \pm 0.1$ & - & - & - & - & $-25.4 \pm 0.4$ & - & $-26.0 \pm 0.4$ \\
\hline BghiP & $-29.0 \pm 0.1$ & - & - & - & - & $-25.6 \pm 0.4$ & - & $-25.2 \pm 0.2$ \\
\hline$\delta^{13} \mathrm{C}(\% \circ)$ & Green oak & kermès oak & Cork oak & Cypress(1) & Cypress (2) & \multicolumn{2}{|c|}{ Eucalyptus Moroccan coal } & Mediterranean False-Brome \\
\hline Phen & $-28.2 \pm 0.1$ & - & - & $-27.7 \pm 0.8$ & $-28.8 \pm 0.4$ & \multicolumn{2}{|l|}{-} & - \\
\hline Fluo & $-31.3 \pm 0.4$ & $-29.6 \pm 0.1$ & $-30.3 \pm 0.7$ & - & - & \multicolumn{2}{|l|}{-} & $-32.0 \pm 0.1$ \\
\hline Pyr & $-30.4 \pm 0.3$ & $-28.7 \pm 0.1$ & $-29.0 \pm 0.4$ & $-27.7 \pm 0.1$ & - & \multicolumn{2}{|c|}{$-28.7 \pm 0.3$} & $-31.4 \pm 0.1$ \\
\hline $\mathrm{BaA}$ & $-29.4 \pm 0.2$ & $-28.7 \pm 0.3$ & $-28.7 \pm 0.3$ & $-27.5 \pm 0.4$ & $-28.3 \pm 0.5$ & \multicolumn{2}{|c|}{$-28.4 \pm 0.4$} & $-30.2 \pm 0.2$ \\
\hline Chrys & $-29.8 \pm 0.5$ & $-29.1 \pm 0.4$ & $-29.4 \pm 0.4$ & $-28.3 \pm 0.2$ & $-30.0 \pm 0.7$ & \multicolumn{2}{|c|}{$-28.8 \pm 0.5$} & $-31.7 \pm 0.3$ \\
\hline $\mathrm{BkF}$ & $-30.0 \pm 0.1$ & $-29.9 \pm 0.3$ & $-29.3 \pm 0.5$ & - & - & \multicolumn{2}{|l|}{-} & $-31.3 \pm 0.3$ \\
\hline $\mathrm{BeP}$ & $-28.9 \pm 0.1$ & $-29.1 \pm 0.3$ & $-29.1 \pm 0.5$ & - & - & \multicolumn{2}{|l|}{-} & $-30.9 \pm 0.1$ \\
\hline $\mathrm{BaP}$ & $-30.3 \pm 0.2$ & $-29.8 \pm 0.3$ & $-29.4 \pm 0.4$ & - & - & \multicolumn{2}{|l|}{-} & $-31.2 \pm 0.3$ \\
\hline IP & - & - & - & - & - & \multicolumn{2}{|l|}{-} & - \\
\hline BghiP & - & - & - & - & - & \multicolumn{2}{|l|}{-} & - \\
\hline
\end{tabular}

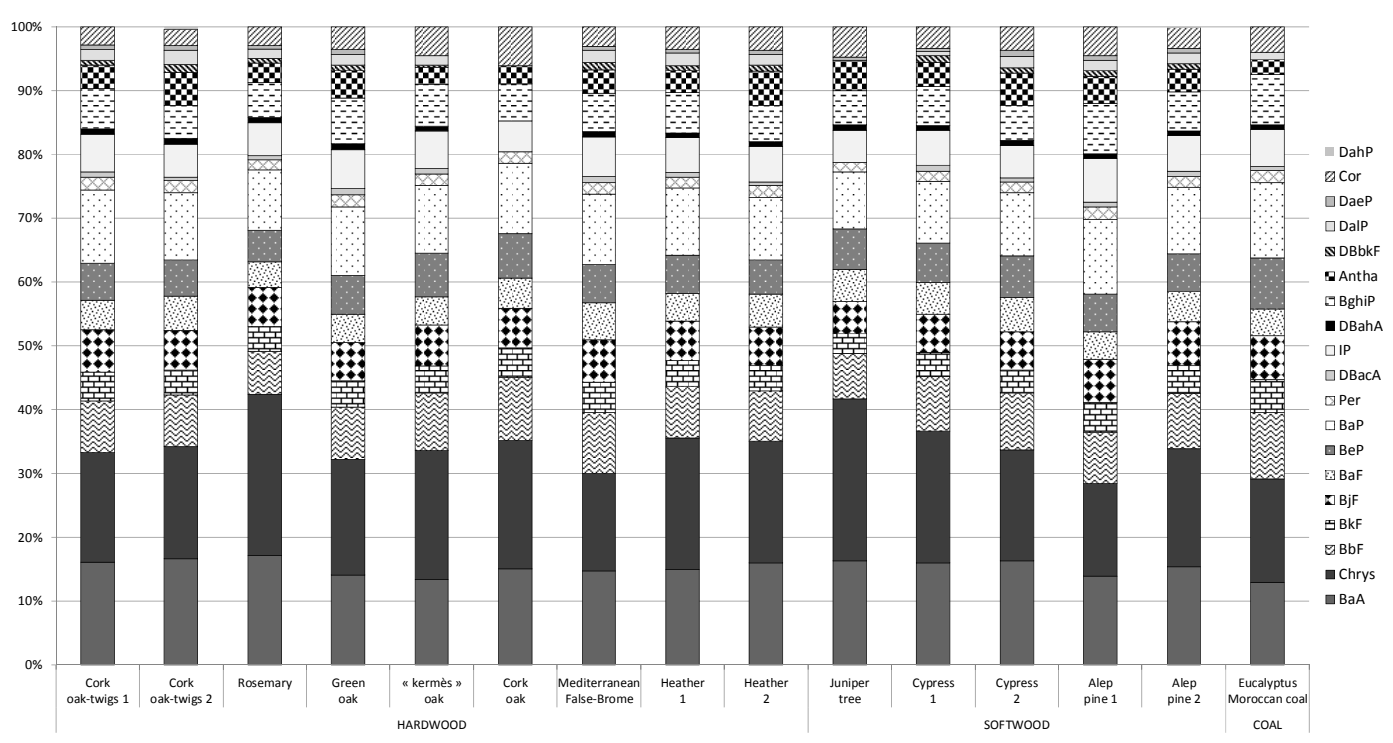

Fig. 2. Molecular fingerprints of particulate-PAHs from wood combustion.

species, except for sugarcane combustion. Indeed, this plant is a " $\mathrm{C}_{4}$ plant" including a photosynthetic pathway different from other studied woods which are " $\mathrm{C}_{3}$ plants". This difference may be explained by the way of PAH formation during the combustion of both plant families. Finally, $[\mathrm{IP}] /([\mathrm{IP}]+[\mathrm{BghiP}])$ ratios are significantly different between various areas of interest. A large variation is observed for wood combustions in Portugal (Gonçalves et al., 2008) as described before. Studies performed in the USA are significantly different presenting diagnostic ratios reported by Fine et al. $(2001,2002)$ and Rogge et al. (1998) in the ranges of $0.6-0.7$ and $0.2-0.3$ respectively. Note that combustion studies were not performed in the same conditions: Rogge et al. (1998) sampled particulate matter along the chimney during wood combustion and fuelled regularly the fire with wood logs whereas Fine et al. $(2001,2002)$ performed the sampling four meters above the fire and injected cold air to cool the smoke allowing organic vapours to condense.

To conclude, variations of diagnostic ratios are not significant to apportion combustion of various wood species. Differences observed between the different reported studies may arise from the nature of woods but also from the combustion conditions (flaming or smoldering fires, time of burning, moisture content...), type of fireplace facilities (domestic fireplace or laboratory experiments) or conditions at the beginning of fire (addition of fuel, newspapers...). Including all 


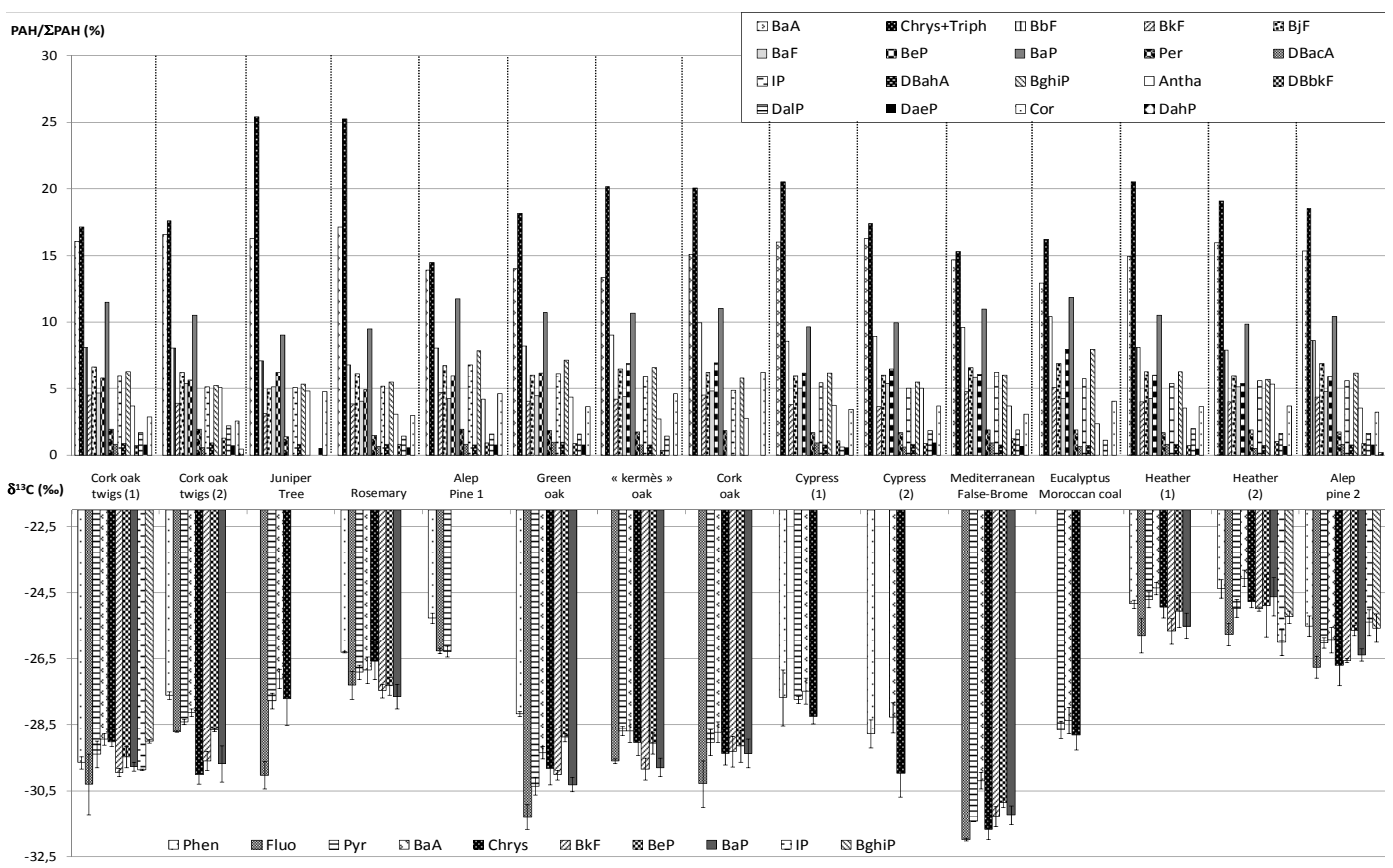

Fig. 3. Stable-carbon isotopic compositions of particulate-PAHs from different wood combustions compared with their molecular fingerprints.

these considerations, it appears sometimes difficult to compare results from different studies, especially because of variations of gas-particles partitioning and PAH profiles. Nevertheless, whatever the study, diagnostic ratios are not significantly different for the woods from the same area meaning that this approach is not sufficient to clearly differentiate the origins of particulate matter. Therefore, it was decided in this work to complete the simple molecular approach by the determination of molecular isotopic compositions of particulate-PAHs.

\subsection{Molecular stable-carbon isotopic compositions of PAHs}

Molecular isotopic compositions of PAHs were determined for the panel of woods considered in this work (Table 7). Due to the low quantities of particulate-PAHs on remaining filters after $\mathrm{GC} / \mathrm{MS}$ and the limits of quantification of GC/C/IRMS, especially for high molecular weight compounds, some molecular isotopic compositions could not be determined, explaining the differences of isotopic profiles of wood species (Table 7 and Fig. 3). Note that quoted uncertainties correspond to three replicates of analysis and range from 0.1 to $0.9 \%$, coinciding well with uncertainties determined with standard solutions (see previous sections) and reference materials (Guillon et al., 2013b). When performing an error propagation analysis, errors were enlarged, accounting for global both statistical and systematic uncertainties. Considering the reproducibility of standard isotopic measurements of $0.5 \%$ (see above), it was confirmed that isotopic compositions of PAHs is independent of the burning type, as expected. However, differentiation among investigated wood species remained significant. Considering all the panel of PAHs, two groups of woods were differentiated. The first including rosemary, alep pine 1 and 2 and heathers is characterised by $\delta^{13} \mathrm{C}$ enriched in ${ }^{13} \mathrm{C}$ with isotopic compositions between -27.6 and $-24.1 \%$. The second group composed of the different oaks, Mediterranean false-brome, eucalyptus Moroccan coal, juniper tree and cypresses is characterised by isotopic compositions in the range of -32 to $-27.1 \%$. For all the PAH, molecular isotopic signatures of heathers are enriched in ${ }^{13} \mathrm{C}$ whereas those of Mediterranean false-brome are depleted in ${ }^{13} \mathrm{C}$, meaning that isotopic measurements could differentiate these wood species from others. No similarities are observed for the isotopic profiles and each compound could be analysed separately in order to differentiate wood species (Fig. 3). Regarding the small uncertainties of measurements, it is possible in this study to focus the analysis on some compounds of interest, and not on the panel of PAHs. Indeed, molecular isotopic compositions of each compound allow differentiation of at least the half of the wood species signatures (Table 7). For example, phenanthrene isotopic compositions are significantly different between all woods studied in this work and isotopic signatures of cypress and oaks are characterised by $\delta^{13} \mathrm{C}$ lower than those of heathers, pines and rosemary. Regarding the results for benzo(e)pyrene, the isotopic compositions of heathers and alep pine 2 are enriched in ${ }^{13} \mathrm{C}$ compared to those of other woods. As underlined with phenanthrene 


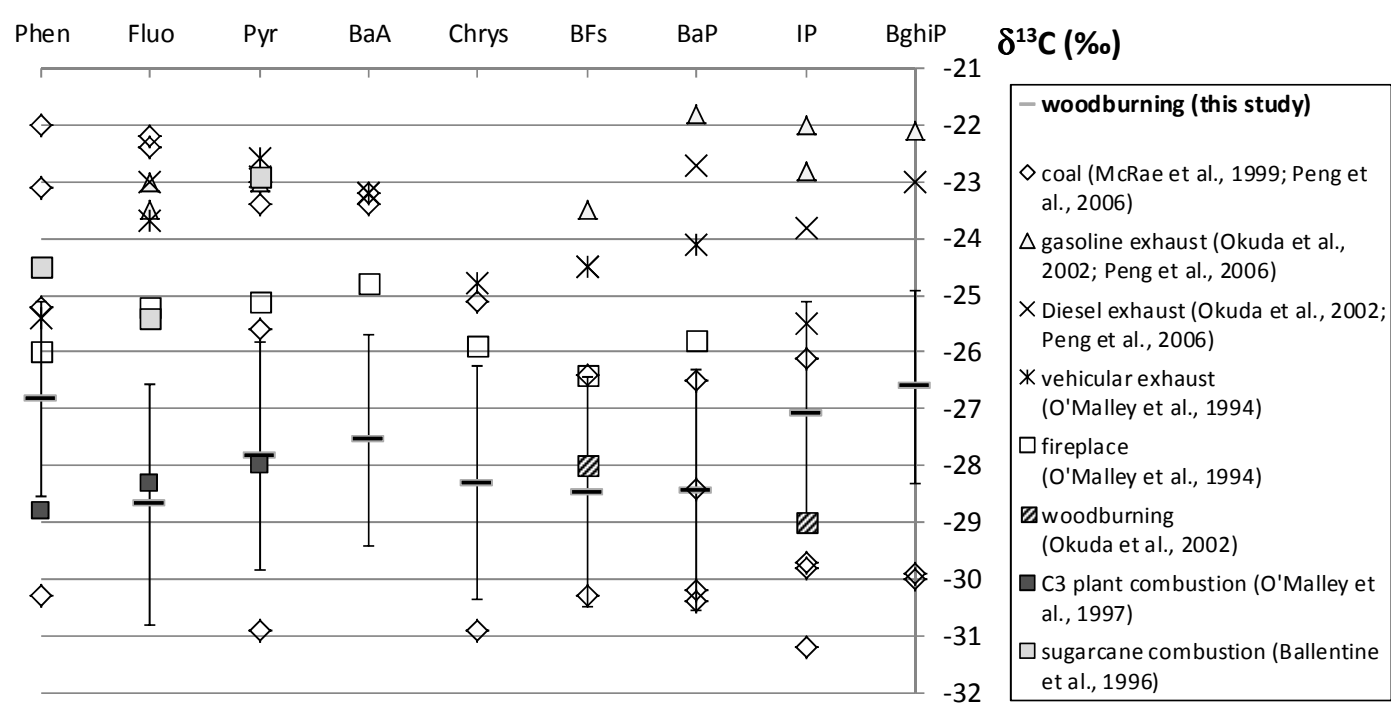

Fig. 4. Comparison of molecular isotopic compositions of particulate-PAHs from wood combustion with results from the literature.

and benzo(e)pyrene data, isotopic compositions do not allow separation of hardwoods from softwoods and the variations of $\delta^{13} \mathrm{C}$ are probably not induced by this repartition of species (Fig. 3). Nevertheless, the uncertainties on these measurements of isotopic compositions allow differentiation of the origin of particulate-PAHs between the different wood species, by combining the results of several PAH isotopic compositions.

Several reference values of molecular isotopic compositions of particulate-PAHs from different sources are presented in Fig. 4 and compared with the results of this study. First, note that all PAH isotopic measurements reported in this work are consistent with previous results reported by O'Malley et al. (1994, 1997) and Okuda et al. (2002), concerning C3 plant combustion, fireplace and woodburning. The variations of isotopic signatures of particulate-PAHs are reported in the range of -26.6 to $-12.9 \%$ o for vehicle exhausts (O'Malley et al., 1994; Okuda et al., 2002; Peng et al., 2006). Most of PAH isotopic compositions allow differentiation of wood combustions and vehicle exhaust, except phenanthrene and indeno(1,2,3-c,d)pyrene whose isotopic compositions are almost the same for these two kinds of origins. Nevertheless, coal combustion signatures are difficult to differentiate from woodburnings, especially for benzofluoranthenes, benzo(a)pyrene and indeno(1,2,3-c,d)pyrene. The main reason is that results from literature are not consistent and the range of isotopic compositions for coal combustion is large: $\delta^{13} \mathrm{C}$ between -22 and $-31.2 \%$ o depending on the origin of the coal and the conditions of preparation (temperature, process...). Consequently, prior to any application of this isotopic approach, a partial knowledge of potential sources involved in the pollution is often necessary and especially if any coal combustion is involved in the particulate pollution.

\section{Conclusions}

In this study, the methodology of source apportionment by the determination of molecular isotopic compositions $\left(\delta^{13} \mathrm{C}\right)$ of particulate-PAHs was applied on different samples of particles arising from the combustion of ten different woods and coal from the Mediterranean Basin. Combustion of woods was performed under controlled conditions in a burning chamber in order to compare the nature of the woods (hardwood vs. softwood), wood species and conditions of burning (flaming vs. smoldering). After the validation of the full analytical procedure, concentrations of thirty-one PAHs were determined by GC/MS and molecular isotopic compositions of ten PAHs were measured for all the panel of wood particles. Molecular and isotopic approaches were applied on this set of samples in order to identify the relevant tools for differentiating wood species. The molecular approach confirms that molecular fingerprints are constant whatever the wood species and the conditions of combustion. Comparing our results with previous works reporting on particulate matter from wood burnings at the emission (Rogge et al., 1998; Fine et al., 2001 and 2002; Oros et al., 2006; Gonçalves et al., 2008; Wang et al., 2009), some reference diagnostic ratios appear constant in the different areas of interest ([Fluo $] /([$ Fluo $]+[\mathrm{Pyr}])$, $[\mathrm{Pyr}] /[\mathrm{BaP}]$ and $[\mathrm{BaP}] /[\mathrm{BghiP}])$. Even if some ratios seem to allow apportionment of wood burnings from Asia to European and North American origins (for instance $[\mathrm{Phen}] /([\mathrm{Phen}]+[$ Anth $]$ ) and $[\mathrm{BaA}] /[\mathrm{BaP}])$, (i) the differences of such ratios within a region are larger than those measured between the regions (ii) they are often in the same range as those of vehicle exhausts, revealing the limitation of this methodology. 
Therefore, it is preferable to use molecular isotopic compositions of particulate-PAHs for all the panel of woods, wood species being characterised by different isotopic signatures depending on the PAH of interest. Note that isotopic composition of PAHs is confirmed to be independent of the burning type (flaming or smoldering), as expected. The isotopic signatures of wood burnings from the Mediterranean Basin coincide well with previous wood combustion data from the literature (O'Malley et al., 1997; Okuda et al., 2002) and significantly different from those reported for vehicle exhaust or fireplace soot, confirming the interest of the isotopic methodology for the apportionment of the various sources of particulate matter. Our results also confirm the necessity to measure isotopic compositions of particulate-PAHs at the emission for a larger variety of sources, such as wood species in this study, but also for others origins such as vehicle exhausts (Diesel and gasoline) or coal combustion. The large variability of isotopic compositions for wood combustion particles represent the large variety of wood species that may occur in the nature during opened fires widespread in this arid area.

\section{Supplementary material related to this article is available online at: http://www.atmos-chem-phys.net/13/ 2703/2013/acp-13-2703-2013-supplement.pdf.}

Acknowledgements. The authors wish to thank the ChArMEx Programme supported by the Institut National des Sciences de l'Univers (INSU) of CNRS, through the MISTRALS-ChArMEx programme and the Aquitaine Region for their financial Supports. The authors also gratefully acknowledge Cathy Liousse (Laboratoire d'Aérologie, LA-Toulouse) for organizing experiments of wood combustion in the burning chamber of Lannemezan and the Laboratoire de Glaciologie et Géophysique de l'Environnement (LGGE-Grenoble) for the sharing of their results on OC and EC before publication.

\section{Edited by: R. Holzinger}

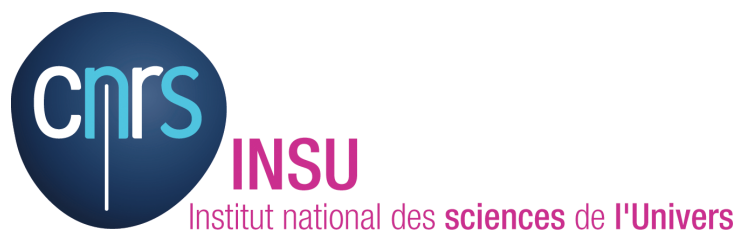

The publication of this article is financed by CNRS-INSU.

\section{References}

Alves, C. A., Gonçalves, C., Evtyugina, M., Pio, C. A., Mirante, F. and Puxbaum, H.: Particulate organic compounds emitted from experimental wildland fires in a
Mediterranean ecosystem, Atmos. Environ., 44, 2750-2759, doi:10.1016/j.atmosenv.2010.04.029, 2010.

Amoako, J., Ansa-Asare, O. D., Karikari, A. Y. and Dartey, G.: Levels of polycyclic aromatic hydrocarbons (PAHs) in the Densu River Basin of Ghana, Environ. Monit. Assess., 174, 471-480, doi:0.1007/s10661-010-1471-y, 2011.

Atkinson, R. and Arey, J.: Atmospheric chemistry of gas-phase polycyclic aromatic hydrocarbons: Formation of atmospheric mutagens, Environ. Health Persp., 102 (suppl. 4), 117-126, 1994.

Ballentine, D. C., Macko, S. A., Turekian, V. C., Gilhooly, W. P., and Martincigh, B.: Compound specific isotope analysis of fatty acids and polycyclic aromatic hydrocarbons in aerosols: Implications for biomass burning, Org. Geochem., 25, 97-104, doi:10.1016/S0146-6380(96)00110-6, 1996.

Bendle, J., Kawamura, K., Yamazaki, K., and Niwai, T.: Latitudinal distribution of terrestrial lipid biomarkers and n-alkane compound-specific stable carbon isotope ratios in the atmosphere over the western Pacific and Southern Ocean, Geochim. Cosmochim. Acta, 71, 5934-5955, 2007.

Birch, M. E. and Cary, R. A.: Elemental carbon-based method for occupational monitoring of particulate diesel exhaust: Methodology and exposure issues, Analyst, 121, 1183-1190, 1996.

Cavalli, F., Viana, M., Yttri, K. E., Genberg, J., and Putaud, J. P.: Toward a standardised thermal-optical protocol for measuring atmospheric organic and elemental carbon: the EUSAAR protocol, Atmos. Meas. Tech., 3, 79-89, doi:10.5194/amt-3-79-2010, 2010.

Dallarosa, J. B., Teixeira, E. C., Pires, M., and Fachel, J.: Study of the profile of polycyclic aromatic hydrocarbons in atmospheric particles $\left(\mathrm{PM}_{10}\right)$ using multivariate methods, Atmos. Environ., 39, 6587-6596, doi:10.1016/j.atmosenv.2005.07.034, 2005.

Desaules, A., Ammann, S., Blum, F., Brändli, R. C. Bucheli, T. D., and Keller, A.: PAH and PCB in soils of Switzerland status and critical review, J. Environ. Monitor., 10, 1265-1277, doi:10.1039/b807206j, 2008.

Eiguren-Fernandez, A., Miguel, A. H., Froines, J. R., Thurairatnam, S., and Avol, E. L.: Seasonal and spatial variation of polycyclic aromatic hydrocarbons in vapor-phase and $\mathrm{PM}_{2.5}$ in Southern California urban and rural communities, Aerosol Sci. Tech., 38, 447-455, doi:10.1080/02786820701213511, 2004.

El Haddad, I., Marchand, N., Wortham, H., Piot, C., Besombes, J.L., Cozic, J., Chauvel, C., Armengaud, A., Robin, D., and Jaffrezo, J.-L.: Primary sources of $\mathrm{PM}_{2.5}$ organic aerosol in an industrial Mediterranean city, Marseille, Atmos. Chem. Phys., 11, 2039-2058, doi:10.5194/acp-11-2039-2011, 2011.

Fine, P. M., Cass, G. R., and Simoneit, B. R. T.: Chemical characterization of fine particle emissions from fireplace combustion of woods grown in the North-eastern United States, Environ. Sci. Technol., 35, 2665-2675, doi:10.1021/es001466k, 2001.

Fine, P. M., Cass, G. R., and Simoneit, B. R. T.: Chemical characterization of fine particle emissions from the fireplace combustion of woods grown in the Southern United States, Environ. Sci. Technol., 36, 1442-1451, doi:10.1021/es0108988, 2002.

Fine, P. M., Cass, G. R., and Simoneit, B. R. T.: Chemical characterization of fine particle emissions from the wood stove combustion of prevalent United States tree species, Environ. Eng. Sci., 21, 705-721, doi:10.1089/ees.2004.21.705, 2004.

Galarneau, E.: Source specificity and atmospheric processing of airborne PAHs: implications for source apportionment, Atmos. 
Environ., 42, 8139-8149, doi:10.1016/j.atmosenv.2008.07.025, 2008.

García-Alonso, S., Pérez-Pastor, R. M., Sevillano-Castaño, M. L., Escolano, O., and García-Frutos, F. J.: Influence of particle size on the quality of PAH concentration measurements in a contaminated soil, Polycycl. Aromat. Comp., 28, 67-83, doi:10.1080/10406630701815253, 2008.

Garivait, S.: Approche physico-chimique de la formation des composés produits par les feux de savane - Développement d'un modèle dynamique basé sur les lois d'équilibres thermochimiques, PhD thesis, University of Paris VII - Denis Diderot, France, 352 pp., 1995.

Gonçalves, C., Alves, C., Evtyugina, M., Mirante, F., Pio, C., Caseiro, A., Schmidl, C., Bauer, H., and Carvalho, F.: Characterisation of $\mathrm{PM}_{10}$ emissions from woodstove combustion of common woods grown in Portugal, Atmos. Environ., 44, 4474-4480, doi:10.1016/j.atmosenv.2010.07.026, 2010.

Guillon, A.: Etude de la composition isotopique moléculaire comme traceur de source qualitative et quantitative des hydrocarbures aromatiques polycycliques particulaires dans l'atmosphère, $\mathrm{PhD}$ thesis, EPOC, University of Bordeaux, France, 383 pp., 2011.

Guillon, A., Riva, M., Le Ménach, K., Budzinski, H., and Villenave, E.: Effects of oxidation pathways and photochemistry on the molecular stable-carbon isotopic compositions of particulate PAHs, Atmos. Environ., submitted, 2013a.

Guillon, A., Le Ménach, K., Leoz-Garziandia, E., Budzinski, H., and Villenave, E.: Source apportionment of particulate Polycyclic Aromatic Hydrocarbons (PAHs) using ${ }^{13} \mathrm{C}$ molecular isotopic approach, Sci. Tot. Environ., submitted, 2013b

Guo, H., Lee, S. C., Ho, K. F., Wang, X. M. and Zou, S. C.: Particle-associated polycyclic aromatic hydrocarbons in urban air of Hong Kong, Atmos. Environ., 37, 5307-5317, doi:10.1016/j.atmosenv.2003.09.011, 2003.

IARC, Agents Classified by the IARC Monographs, Volumes 1-102: http://monographs.iarc.fr/ENG/Classification/ ClassificationsAlphaOrder.pdf, last access: June 2011.

Jensen, H., Reimann, C., Finne, T. E., Ottesen, R. T., and Arnoldussen, A.: PAH-concentrations and compositions in the top $2 \mathrm{~cm}$ of forest soils along a $120 \mathrm{~km}$ long transect through agricultural areas, forests and the city of Oslo, Norway, Environ. Pollut., 145, 829-838, doi:10.1016/j.envpol.2006.05.008, 2007.

Kang, Y., Cheung, K. C., and Wong, M. H.: Mutagenicity, genotoxicity and carcinogenic risk assessment of indoor dust from three major cities around the Pearl River Delta, Environ. Int., 37, 637643, doi:10.1016/j.envint.2011.01.001, 2011.

Latimer, S. and Zheng, J.: The sources, transport and fate of PAHs in the marine environment in: PAHs: an ecotoxicological perspective, John Wiley \& Sons, Douben P. E. T., Chichester, UK, 2003.

Lee, R. G. M., Coleman, P., Jones, J. L., Jones, K. C., and Lohmann, R.: Emission factors and importance of PCDD/Fs, PCBs, PCNs, PAHs and $\mathrm{PM}_{10}$ from the domestic burning of coal and wood in the U.K., Environ. Sci. Technol., 39, 1436-1447, doi:10.1021/es991183w, 2005.

Li, C. K. and Kamens, R. M.: The use of polycyclic aromatic hydrocarbons as source signatures in receptor modelling, Atmos. Environ. - Part A General Topics, 27, 523-532, 1993.

Li, Q., Wang, W., Zhang, H.-W., Wang, Y.-J., Wang, B., Li, L., Li, H.-J., Wang, B.-J., Zhan, J., Whu, M., and Bi X.-H.: develop- ment of a compound-specific carbon isotope analysis method for 2 methyltetrols, biomarkers for secondary organic aerosols from atmospheric isoprene, Anal. Chem., 82, 6764-6769, 2010.

Li, Z., Porter, E. N., Sjödin, A., Needham, L. L., Lee, S., Russell, A. G., and Mulholland, J. A.: Characterization of $\mathrm{PM}_{2.5}$-bound polycyclic aromatic hydrocarbons in Atlanta-seasonal variations at urban, suburban and rural ambient air monitoring sites, Atmos. Environ., 43, 4187-4193, doi:10.1016/j.atmosenv.2009.05.031, 2009.

Marchand, N., Besombes, J. L., Chevron, N., Masclet, P., Aymoz, G., and Jaffrezo, J. L.: Polycyclic aromatic hydrocarbons (PAHs) in the atmospheres of two French alpine valleys: sources and temporal patterns, Atmos. Chem. Phys., 4, 11671181, doi:10.5194/acp-4-1167-2004, 2004.

McRae, C., Sun, C.-G., Snape, C. E., Fallick, A. E., and Taylor, D.: $\delta^{13} \mathrm{C}$ values of coal-derived PAHs from different processes and their application to source apportionment, Org. Geochem., 30, 881-889, doi:10.1016/S0146-6380(99)00072-8, 1999.

Meador, J. P.: Bioacumulation of PAHs in marine invertebrates, in: PAHs: an ecotoxicological perspective, John Wiley \& Sons, Douben P. E. T., Chichester, UK, 2003.

Odabasi, M., Vardar, N., Sofuoglu, A., Tasdemir, Y., and Holsen, T. M.: Polycyclic aromatic hydrocarbons (PAHs) in Chicago air, Sci. Total Environ., 227, 57-67, doi:10.1016/S00489697(99)00004-2, 1999.

Okuda, T., Kumata, H., Zakaria, M. P., Naraoka, H., Ishiwatari, R. and Takada, H.: Source identification of Malaysian atmospheric polycyclic aromatic hydrocarbons nearby forest fires using molecular and isotopic compositions, Atmos. Environ., 36, 611-618, doi:10.1016/S1352-2310(01)00506-4, 2002.

O’Malley, V. P., Abrajano Jr, T. A., and Hellou, J.: Determination of the ratios of individual PAH from environmental samples: can PAH sources be apportioned?, Org. Geochem., 21, 809-822, 1994.

O’Malley, V. P., Burke, R. A., and Schlotzhauer, W. S.: Using GCMS/Combustion/IRMS to determine the ${ }^{13} \mathrm{C} /{ }^{12} \mathrm{C}$ ratios of individual hydrocarbons produced from the combustion of biomass materials-application to biomass burning, Org. Geochem., 27, 567-581, doi:10.1016/S0146-6380(97)00087-9, 1997.

Oros, D. R., Abas, M. R. b., Omar, N. Y. M. J., Rahman, N. A., and Simoneit, B. R. T.: Identification and emission factors of molecular tracers in organic aerosols from biomass burning: Part 3. Grasses, Appl. Geochem., 21, 919-940, doi:10.1016/j.apgeochem.2006.01.008, 2006.

Peng, L., You, Y., Bai, Z., Zhu, T., Xie, K., Feng, Y.C., and Li, Z.: Stable carbon isotope evidence for origin of atmospheric polycyclic aromatic hydrocarbons in Zhengzhou and Urumchi, China, Geochem. J., 40, 219-226, doi:10.2343/geochemj.40.219, 2006.

Perugini, M., Visciano, P., Giammarino, A., Manera, M., Di Nardo, W., and Amorena, M.: Polycyclic aromatic hydrocarbons in marine organisms from the Adriatic Sea, Italy, Chemosphere, 66, 1904-1910, doi:10.1016/j.chemosphere.2006.07.079, 2007.

Pham-Van-Dinh, Lacaux, J.-P., Serpolay, R.: Cloud-active particles from African savanna combustion experiments, Atmos. Res., 31, 41-58, 1994.

Ravindra, K., Sokhi, R., and Van Grieken, R.: Atmospheric polycyclic aromatic hydrocarbons: Source attribution, emission factors and regulation, Atmos. Environ., 42, 2895-2921, 
doi:10.1016/j.atmosenv.2007.12.010, 2008.

Ré-Poppi, N. and Santiago-Silva, M.: Polycyclic aromatic hydrocarbons and other selected organic compounds in ambient air of Campo Grande City, Brazil, Atmos. Environ., 39, 2839-2850, doi:10.1016/j.atmosenv.2004.10.006, 2005.

Rogge, W. F., Hildemann, L. M., Mazurek, M. A., Cass, G. R., and Simoneit, B. R. T.: Sources of fine organic aerosol. 2. Noncatalyst and catalyst-equipped automobiles and heavy-duty diesel trucks, Environ. Sci.Technol., 27, 636-651, 1993.

Rogge, W. F., Hildemann, L. M., Mazurek, M. A., and Cass, G. R.: Sources of fine organic aerosol. 9. Pine, oak and synthetic log combustion in residential fireplaces, Environ. Sci. Technol., 32, 13-22, doi:10.1021/es960930b, 1998.

Sang, X. F., Gensch, I., Laumer, W., Kammer, B., Chan, C. Y., Engling, G., Wahner, A., Wissel, H., and Kiendler-Scharr, A.: Stable carbon isotope ratio analysis of anhydrosugars in biomass burning aerosol particles from source samples, Environ. Sci. Technol., 46, 3312-3318, 2012.

Schantz, M. M., Nichols, J. J., and Wise, S. A.: Evaluation of pressurized fluid extraction for the extraction of environmental matrix reference materials, Anal. Chem., 69, 4210-4219, 1997.

Schmidl, C., Marr, I. L., Caseiro, A., Kotianová, P., Berner, A., Bauer, H., Kasper-Giebl, A., and Puxbaum, H.: Chemical characterisation of fine particle emissions from wood stove combustion of common woods growing in midEuropean Alpine regions, Atmos. Environ., 42, 126-141, doi:10.1016/j.atmosenv.2007.09.028, 2008.

Sheesley, R. J., Schauer, J. J., Smith, T. J., Garshick, E., Laden, F., Marref, L. C., and Molina, L. T.: Assessment of diesel particulate matter exposure in the workplace: freight terminals, J. Environ. Monitor., 10, 305-314, doi:10.1039/b715429a, 2008.

Sheesley, R. J., Andersson, A., and Gustafsson, O.: Source characterization of organic aerosols using Monte Carlo source apportionment of PAHs at two South Asian receptor sites, Atmos. Environ., 45, 3874-3881, doi:10.1016/j.atmosenv.2011.01.031, 2011.

Srogi, K.: Monitoring of environmental exposure to polycyclic aromatic hydrocarbons: a review, Environ. Chem. Lett., 5, 169-195, doi:10.1007/s10311-007-0095-0, 2007.
Sun, C., Cooper, M., and Snape, C. E.: Use of compound-specific $\delta^{13} \mathrm{C}$ and $\delta \mathrm{D}$ stable isotope measurements as an aid in the source apportionment of polyaromatic hydrocarbons, Rapid Commun. Mass Sp., 17, 2611-2613, 2003.

Van Drooge, B. L. and Ballesta, P. P.: Seasonal and daily source apportionment of polycyclic aromatic hydrocarbon concentrations in $\mathrm{PM}_{10}$ in a semirural European area, Environ. Sci. Technol., 4, 7310-7316, doi:10.1021/es901381a, 2009.

Van Drooge, B. L., López, J., Fernández, P., Grimalt, J. O., and Stuchlík, E.: Polycyclic aromatic hydrocarbons in lake sediments from the High Tatras, Environ. Pollut., 159, 1234-1240, doi:10.1016/j.envpol.2011.01.035, 2011.

Wang, Z., Bi, X., Sheng, B., and Fu, J.: Characterization of organic compounds and molecular tracers from biomass burning smoke in South China I: Broad-leaf trees and shrubs, Atmos. Environ., 43, 3096-3102, doi:10.1016/j.atmosenv.2009.03.012, 2009.

Wise, S. A. and Watters Jr, R. L.: Certificate of analysis standard reference material 1650b, Gaithersburg, MD, 2006.

Wise, S. A. and Watters Jr, R. L.: Certificate of analysis standard reference material 1649a, Gaithersburg, MD, 2007.

Wise, S. A. and Watters Jr, R. L.: Certificate of analysis standard reference material 2975, Gaithersburg, MD, 2009.

Yan, B., Zheng, M., Hu, Y., Ding, X., Sullivan, A. P., Weber, R. J., Baek, J., Edgerton, E. S. and Russell, A. G.: Roadside, urban and rural comparison of primary and secondary organic molecular markers in ambient $\mathrm{PM}_{2.5}$, Environ. Sci. Technol., 43, 42874293, doi:10.1021/es900316g, 2009.

Yang, H.-H. and Chen, C.-M.: Emission inventory and sources of polycyclic aromatic hydrocarbons in the atmosphere at a suburban area in Taiwan, Chemosphere, 56, 879-887, doi:10.1016/j.chemosphere.2004.05.031, 2004.

Yin, J., Harrison, R. M., Chen, Q., Rutter, A., and Schauer, J. J.: Source apportionment of fine particles at urban background and rural sites in the UK atmosphere, Atmos. Environ., 44, 841-851, doi:10.1016/j.atmosenv.2009.11.026, 2010.

Zhang, L., Bai, Z., You, Y., Wu, J., Feng, Y., and Zhu, T.: Chemical and stable carbon isotopic characterization for PAHs in aerosol emitted from two indoor sources, Chemosphere, 75, 453-461, doi:10.1016/j.chemosphere.2008.12.063, 2009. 